INTER NATIONAL MONETARY FUND
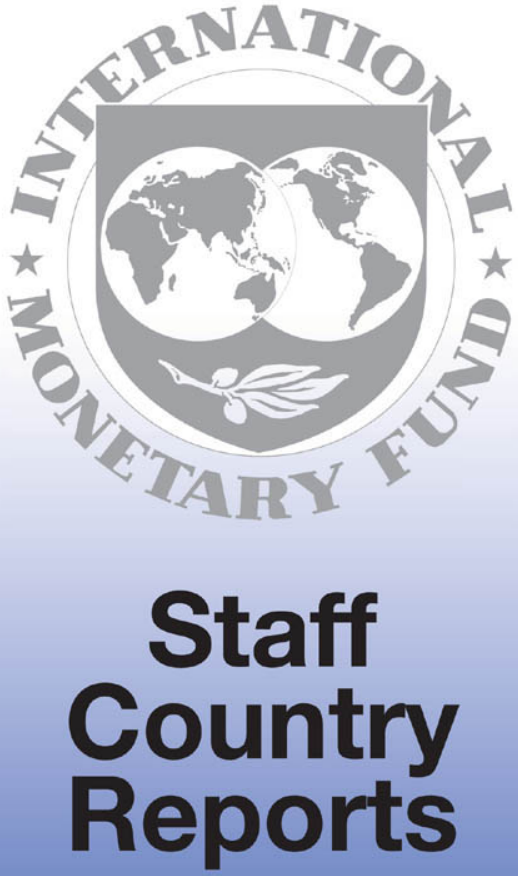


\title{
Pakistan: Use of Fund Resources-Request for Emergency Assistance—Staff Report; Press Release on the Executive Board Discussion; and Statement by the Executive Director for Pakistan.
}

In the context of the use of fund resources - request for emergency assistance, the following documents have been released and are included in this package:

- $\quad$ The staff report for the Use of Fund Resources-Request for Emergency Assistance, prepared by a staff team of the IMF, following discussions that ended on September 3, 2010, with the officials of Pakistan on economic developments and policies. Based on information available at the time of these discussions, the staff report was completed on September 10, 2010. The views expressed in the staff report are those of the staff team and do not necessarily reflect the views of the Executive Board of the IMF.

- $\quad$ A Press Release summarizing the views of the Executive Board as expressed during its September 15, 2010 discussion of the staff report that completed the request and/or review.

- A statement by the Executive Director for Pakistan.

The document listed below has been or will be separately released.

Letter of Intent sent to the IMF by the authorities of Pakistan*

*Also included in Staff Report

The policy of publication of staff reports and other documents allows for the deletion of market-sensitive information.

\author{
Copies of this report are available to the public from \\ International Monetary Fund • Publication Services \\ $70019^{\text {th }}$ Street, N.W. • Washington, D.C. 20431 \\ Telephone: (202) 623-7430 • Telefax: (202) 623-7201 \\ E-mail: publications@imf.org Internet: http://www.imf.org
}

\section{International Monetary Fund Washington, D.C.}


INTERNATIONAL MONETARY FUND

PAKISTAN

\title{
Use of Fund Resources-Request for Emergency Assistance
}

\author{
Prepared by the Middle East and Central Asia Department \\ (In consultation with other departments)
}

Approved by Alfred Kammer and James Roaf

September 10, 2010

Background. Pakistan has suffered massive floods. One-fifth of the country has been flooded, about 10 percent of the population has been directly affected, nearly two million homes have been destroyed or damaged, and there has been extensive damage to roads, telecom and energy infrastructure, and crops and livestock.

Discussions. The Pakistani authorities have requested financial assistance under the Fund's policy for Emergency Natural Disaster Assistance (ENDA). In the attached letter, they request a single purchase of SDR 296.98 million (28.73 percent of quota) for immediate budget support to provide urgently needed food, shelter, and health services. A staff team of Messrs. Mazarei (head), Kock, Ross and Wieczorek (all MCD) and Mr. Gray (SPR) and Mr. Jonas (FAD) met with a Pakistani delegation comprised of Finance Minister Sheikh, Acting State Bank Governor Anwar, Deputy Chairman of the Planning Commission Haque, and other senior officials at Fund headquarters. Since the discussions, Mr. Shahid Kardar has been appointed State Bank Governor and has endorsed the policies supported by the Stand-By Arrangement (SBA).

IMF SBA. In November 2008, the Executive Board approved an SBA of SDR 5,169 million (500 percent of quota). Access was augmented in August 2009 to SDR 7, 236 million (700 percent of quota), and purchases to date total SDR 4.94 billion. The fourth review of the program was concluded on May 14, 2010. The authorities have reiterated their commitment to the reform program supported by the SBA and hope that the fifth review can be completed in the coming months. 


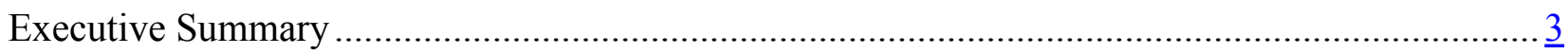

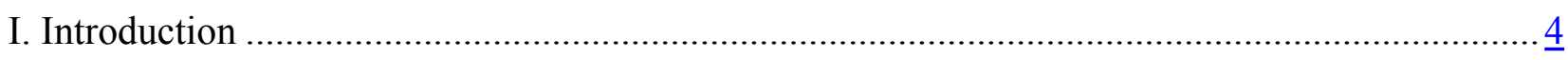

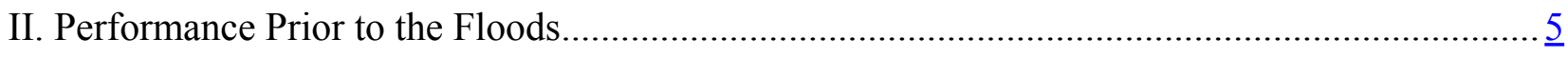

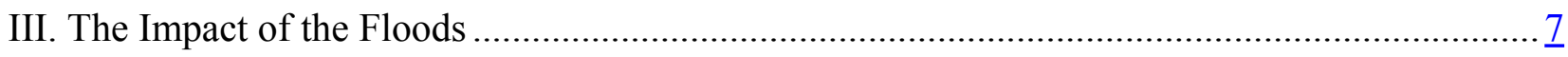

IV. The Authorities' Response and the Need for Assistance................................................. $\underline{9}$

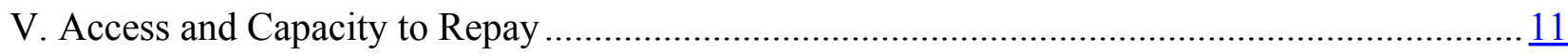

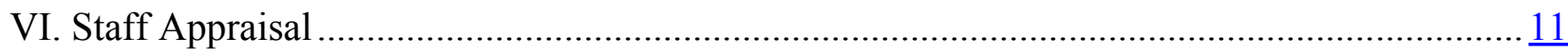

Text Table

1. Macroframework 2009/10-2010/11 ..........................................................................

Figures

1. Selected Economic Indicators ......................................................................... 13

2. Financial Market Indicators ................................................................................... 14

3. Real and External Sectors, 2006/07-2010/11 ........................................................ 15

4. Fiscal Policy Indicators, 2007/08-2010/11 ................................................................. 16

Tables

1. Selected Economic Indicators, 2008/09-2010/11 ............................................................ $\frac{17}{18}$

2. Balance of Payments, 2008/09-2010/11 ........................................................................... 18

3a. Consolidated Government Budget, 2008/09-2010/11 (in billions of Pakistani rupees) ........ 19

3b. Consolidated Government Budget, 2008/09-2010/11 (in percent of GDP)........................ 20

4. Monetary Survey and Analytical Balance Sheet of the State Bank of Pakistan,

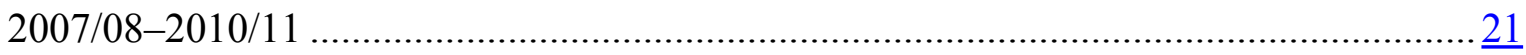

5. Medium-Term Macroeconomic Framework, 2007/08-2014/15 ..................................... 22

6. Indicators of Fund Credit, 2008/09-2015/16 ......................................................... 23

Appendix

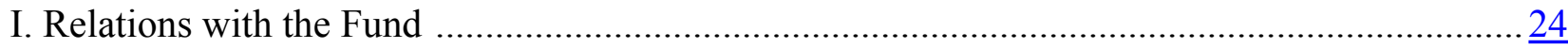

Attachment

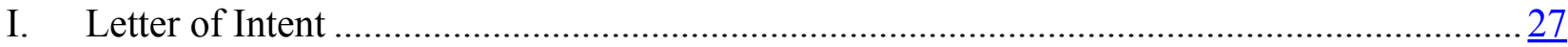




\section{EXECUTIVE SUMMARY}

The floods in Pakistan are a natural disaster of massive proportions. About one-fifth of the country has been flooded and 10 percent of the population has been directly affected. Nearly two million homes have been destroyed or damaged and there is extensive damage to roads, telecom and energy infrastructure, and crops and livestock. Precise estimates are not yet available, but it is clear that the costs arising from the floods (for humanitarian relief and reconstruction) will be in the billions of dollars.

The Pakistani authorities request financial assistance under the Fund's policy for Emergency Natural Disaster Assistance (ENDA). They request a single purchase of SDR 296.98 million (28.73 percent of quota) for immediate budget support. The assistance will be used to provide food, shelter, and health services. The authorities reiterate their commitment to the reform program supported by the SBA and hope that the fifth review can be completed in the coming months.

The economic outlook has deteriorated sharply. The full impact of the floods is not yet known. The IMF staff's preliminary assessment is that, as a result of the floods, real GDP growth is unlikely to exceed $23 / 4$ percent and could be lower. Average annual inflation is projected to rise to $13 \frac{1}{2}$ percent in $2010 / 11$ compared to 11.7 percent in $2009 / 10$ and the balance of payments is expected to weaken by US\$1.6 billion ( 0.8 percent of GDP) in 2010/11 compared to the pre-flood forecast. Budget pressures are also expected as tax collection is likely to be lower and budgetary expenditure is likely to higher. Significant external assistance is needed for rescue and relief operations, and rehabilitation and reconstruction; budgetary grants would be preferable.

The extent of rehabilitation and reconstruction is being assessed. The initial assessment by the World Bank and Asian Development Bank is scheduled to be completed in mid-October. The budget will then need to be revised to accommodate the cost of emergency operations and reconstruction, in light of available financing, and IMF staff will work with the authorities to re-evaluate the macroeconomic framework.

Ensuring accountability and transparency will be an important challenge. The authorities have asked the World Bank to help establish an enhanced monitoring of aid flows to bolster accountability and transparency, which should facilitate larger and more rapid aid disbursements. It should also help with targeting the assistance to the poor and vulnerable groups, who will be hurt most by this natural catastrophe. 


\section{INTRODUCTION}

1. The floods in Pakistan are a natural disaster of massive proportions. Large parts of the country - from Gilgit-Baltistan and Kashmir, through Khyber Pakhtunkhwa province and all along the Indus River through Punjab and Sindh — are flooded. Eighteen million people (over 10 percent of the population) have been directly affected. Although the number of casualties is much lower than in the 2005 earthquake, the damage to economic infrastructure and private property is much larger. ${ }^{1} 1.8$ million homes have been destroyed or damaged and there is extensive damage to roads, telecom and energy infrastructure, and crops and livestock. Precise estimates are not yet available, but it is clear that the costs arising from the floods (for humanitarian relief and reconstruction) will be in the billions of dollars. ${ }^{2}$

\section{Beyond the immediate humanitarian impact, the floods will likely have a significant implication for growth, the balance of payments, and public finances.}

Preliminary estimates suggest a considerable loss of output. The overall impact will critically depend on how the floods will affect agricultural output along the Indus and its tributaries (a 10 percent decline in agricultural output would reduce GDP by over 2 percent). Floods are also disrupting trade, with exports and imports being held up in ports, and electricity production as fuel cannot be delivered to power plants. Public finances are affected with lower revenue collections and higher outlays for needed humanitarian assistance. A revision of the 2010/11 budget will be necessary.

\section{The Pakistani authorities request financial assistance under the Fund's policy for} Emergency Natural Disaster Assistance (ENDA). In the attached letter, they request a single purchase of SDR 296.98 million (28.73 percent of quota) for immediate budget support. ${ }^{3}$ The assistance will be used to provide urgently needed food, shelter, and health services. Financial assistance from the IMF will help meet these financing needs of the government without over-burdening domestic financial markets and depleting foreign exchange reserves, and encourage financing from other sources. In the attached letter, the authorities reiterate their commitment to the reform program supported by the Stand-By Arrangement (SBA) and hope that the fifth review can be completed in the coming months.

\footnotetext{
${ }^{1}$ The main sources for information on the disaster and donors' emergency relief responses are the UN Office for the Coordination of Humanitarian Affairs (www.pakresponse.info/index.php) and the Pakistan Federal Flood commission (www.ffc.gov.pk/lood).

2 The World Bank estimates that damage to crops alone is at least US\$1 billion. Researchers at Ball State University estimate damage to buildings, content, agriculture assets and transportation infrastructure at US\$5.1-7.1 billion (www.cms.bsu.edu/Academics/CentersandInstitutes/BBR/CurrentStudiesandPublications.aspx).

${ }^{3}$ A Memorandum of Understanding between the SBP and the ministry of finance clarifies the treatment of Fund resources for budgetary support, including the ministry of finance's responsibility for meeting debt service charges. The authorities are regularly reporting on balances outstanding at the SBP for budgetary financing.
} 


\section{Performance Prior to the Floods}

4. Before the floods, growth was picking up, but inflation was high and persistent. Provisional estimates indicate real GDP growth of 4 percent in 2009/10, led by large-scale manufacturing, which grew 5 percent annually. In 2009/10 annual average inflation was 11.7 percent, end-period headline inflation 12.7 percent, and core inflation 10.4 percent (broadly unchanged since January). ${ }^{4}$ Based on these developments, prior to the floods, staff had projected a GDP growth rate of $4 \frac{1}{4}$ percent and an annual inflation rate of 11.5 percent for 2010/11.

5. Official reserves had increased and the nominal exchange rate remained stable. The current account deficit narrowed sharply to US $\$ 3.5$ billion in 2009/10 (2 percent of GDP) due to a sharper-than-expected import compression, a continued rebound in exports, and continued growth of remittances. The smaller current account deficit offset lower than expected FDI due to delays in privatization, and large shortfalls in official capital inflows. Official reserves rose to about US\$13 billion at end-June (compared with a projected US\$13.5 billion), but the net foreign assets position of the State Bank of Pakistan (SBP) remained weak at US\$5.9 billion, the equivalent of 1.7 months of import cover. The exchange rate was 85-86 rupee per dollar in May-July and the real exchange rate has appreciated.

6. The 2009/10 budget deficit target was missed by a significant margin. The deficit (excluding grants) reached 6.3 percent of GDP compared to an unadjusted target of 5.1 percent of GDP. Lower revenue and higher provincial spending contributed equally ( 0.6 percent of GDP each) to the deficit overrun. Tax revenue was about 0.3 percentage points of GDP lower than projected, in part related to reorganization of the tax administration and court appeals by taxpayers. Nontax revenue also fell short of target due to lower dividends and profit transfers. While federal spending was tightly controlled and ended up slightly lower than projected, provincial spending - both current and development spending - accelerated at year's end, resulting in an overrun. Meanwhile, the shortfall in foreign financing (including privatization receipts) caused the adjusted program deficit target to tighten by 0.5 percent of GDP to 4.6 percent of GDP; as a result, the margin of nonobservance was 1.7 percent of GDP. The end-June target on government borrowing from the SBP was missed by 0.3 percent of GDP and shortfalls in donor financing meant the ministry of finance was unable to repay to the SBP part of the IMF bridge loan, which at endJune was US $\$ 400$ million higher than programmed. ${ }^{5}$

\footnotetext{
${ }^{4}$ In July 2010, year-on-year headline and core inflation declined to 12.3 and 10.3 percent, respectively.

${ }^{5}$ Part of the third, fourth, and fifth purchases under the SBA were available for budget financing in 2009/10 to meet urgent spending needs (for internally displaced persons and social spending) and were originally envisaged to be repaid by the budget to the SBP as disbursements of the pledges, made at the Tokyo donors conference in April 2009, were received.
} 
7. The 2010/11 approved federal budget targeted a general government deficit of 4 percent of GDP and the authorities immediately implemented a number of measures. On July 1, they raised the general sales tax (GST) rate by 1 percentage point to 17 percent. In addition, they have taken measures to boost the collection of excise and direct taxes that include the withdrawal of capital gains tax exemptions and an increase in the federal excise duty on cigarettes, natural gas, and some other items. Savings on the spending side include cuts in subsidies and a nominal freeze in federal current spending.

8. The further devolution of revenue and spending to provinces has increased the importance of provincial fiscal discipline. The share of tax revenues distributed to provinces rose significantly in 2010/11 under the Seventh National Finance Commission Award. As spending responsibilities have not yet been transferred, the federal budget expected provinces to save most of the additional funds and run surpluses this fiscal year. However, their approved budgets targeted a small deficit and implied a consolidated general government would reach a deficit of 5 percent of GDP, one percentage point higher than targeted. During a staff visit in July, measures were discussed with the authorities to ensure the deficit target of 4 percent of GDP could be met.

9. The prompt introduction of a broad-based VAT (reformed GST) remains a central plank of the authorities' strategy to boost tax revenues. The authorities believe it politically easier to reform the GST to include the substantive features of the VAT (broader base, reduced exemptions, and input crediting) rather than introducing a VAT. Following intensive negotiations with the provinces, an agreement has been reached in principle on the allocation of revenues of a reformed GST on services. A decision has yet to be made on the exact modalities of the introduction of the reformed GST. Fund and Bank staffs are actively discussing these modalities with the ministry of finance and the Federal Board of Revenue (FBR).

10. Efforts continue to improve tax administration to make it taxpayer-friendly and improve compliance. A new annual tax audit plan for FY 2010/11 has been approved. Following the review of experience with tax audits that started last year, the authorities are now moving to risk-based selection criteria. The SBP, together with the FBR, have finalized the design of the Electronic Payment and Refund System that would allow electronic payment of taxes and crediting of refunds by the FBR.

11. Monetary policy was tightened in late July. On July 30, the SBP announced an increase in its policy rate by 50 basis points to 13 percent (with effect from August 2). The accompanying monetary policy statement noted concerns about inflation, fiscal imbalances, 
lower than expected inflows from external sources, and weak revenue. Growth of bank credit to the private sector remains weak at 4⿳⿲丶丶㇒一八厶 percent $y-0-y$ as of August 21.

\section{Financial Soundness Indicators through end-March 2010 deteriorated.}

Nonperforming loans (NPLs) increased from 12.2 percent at end-December 2009 to 13.1 percent at end-March 2010. Further, the risk-weighted capital-to-assets ratio declined from 14.1 to 13.7 percent. An increase in the net NPL-to-capital ratio prompted the SBP to contemplate tightening provisioning requirements, especially in systemically important banks. At the same time, due to the increasing share of t-bills in banks' portfolios, bank liquidity remains high and return on assets and equity has improved.

13. Electricity reform has been delayed. The tariff increase on July 1 was larger than planned earlier (7.6 rather than 6 percent) to help offset the financial impact of the threemonth delay. Discussions on a comprehensive reform strategy for the electricity sector with the World Bank and the Asian Development Bank (ADB) have recently restarted, but an agreement, which is needed to release about US\$1 billion of program loans to finance the 2010/11 budget, has not yet been reached. Nevertheless, subsidy needs for the electricity sector are to be determined and will likely exceed the Rs. 30 billion ( 0.2 percent of GDP) provided in the budget. Meanwhile, new "circular debt" (inter-enterprise arrears) in the energy sector continues to accumulate.

\section{THE IMPACT OF THE FLOODS}

14. The economic outlook has deteriorated sharply as a result of the floods. The agriculture sector - which accounts for 21 percent of GDP and 45 percent of employmenthas been hit particularly hard. An estimated 8 percent of total cropped area has been flooded, with very significant damage to industrial crops (i.e., cotton and sugarcane), wheat, vegetables and fruits, and livestock. Lower agricultural output will reduce domestic demand. Manufacturing output and exports have also been affected. The staff's initial assessment is that real GDP growth is unlikely to exceed $23 / 4$ percent in $2010 / 11$, mainly because of sharply lower agricultural output growth. GDP growth could be even lower if damage to crops exceeds preliminary assessments or if the floods recede at a slower pace than expected. Disruption of supply chains and the agricultural damage have already started to push up prices, especially for food items, while additional demand for building material, medicine, and social services will also contribute to price pressures. Accordingly, the staff projects average annual inflation of $13 \frac{1}{2}$ percent in 2010/11 compared to 11.7 percent in 2009/10. Inflation jumped in August due to a sharp increase in the prices of perishable foods. Headline month-on-month inflation increased by 2.5 percent and year-on-year inflation was 13.2 percent, while core inflation declined to 9.8 percent. 
Text Table 1: Pakistan: Macroframework 2009/10-2010/11

(In percent; unless otherwise stated)

\begin{tabular}{lrrr}
\hline & $2009 / 10$ & \multicolumn{2}{c}{$2010 / 11$} \\
\cline { 3 - 4 } & & Pre-floods & Post-floods \\
\hline Real GDP growth at factor cost & 4.1 & 4.3 & 2.8 \\
CPI inflation (period average) & 11.7 & 11.5 & 13.5 \\
Current account deficit/GDP & -2.0 & -2.5 & -3.1 \\
Memorandum items & & & \\
External debt/GDP & 31.6 & 30.7 & 31.8 \\
Public debt to GDP 1/ & 63.4 & $\ldots$ & $\ldots$ \\
Official reserves/months of imports & 3.7 & 4.6 & 4.6 \\
\hline
\end{tabular}

1/ Including obligations to the IMF.

15. Staff expects the floods to result in a weakening of the 2010/11 balance of payments by US\$1.6 billion ( 0.8 percent of GDP). The current account deficit was expected to increase in 2010/11 even before the floods because of higher imports and slower growth in remittances. With the floods, we now expect a larger current account deficit; imports will rise in the short run as food and other basic goods will need to be sourced from abroad and capital equipment imports will increase for reconstruction. Although the major export plants seem to have escaped physical damage, cotton and textiles exports will likely be lower if the cotton crop is affected significantly. The higher-than-expected trade deficit will be compensated in part by rising remittances, which may approach a record US $\$ 10$ billion. Even so, the current account deficit will likely widen by 0.7 percent of GDP to 3.1 percent of GDP, while private capital flows are projected to decline by about 0.1 percent of GDP.

16. There will be serious pressures on the budget. Tax collection is likely to be lower owing to disruptions in economic activity - though the hardest hit sector, agriculture, is not a significant taxpayer-and possibly weaker compliance. We estimate that in the current quarter tax revenue will fall short by 0.3 percent of GDP and it is probable that the adverse effect on revenue collection will continue for some time. Though it is too early to make more precise estimates, demand for budgetary resources is likely to increase substantially, initially because of the costs of rescue and relief operations, and later because of the huge reconstruction needs. These expected developments underscore the need for a reformed GST to broaden the tax base and enhance tax revenue as well as measures to rein in fiscal contingencies linked with electricity and other sectors. 


\section{NPLs are expected to rise, especially for banks with large exposure to the} agriculture sector. Initial estimates from the SBP put loan losses related to the floods at about Rs. 54 billion, of which Rs. 34 billion are loans to agriculture. Although significant, this is unlikely to materially affect the banking system as total private sector loans amount to close to Rs. 3 trillion.

18. Financial market indicators have deteriorated somewhat. The stock market had picked up in July, but lost 6 percent between end-July and September 8, against an average gain of 2 percent for peer markets. Pakistan's sovereign spread increased by some 80 basis points to 643 basis points between end-July and September 8, against a broadly stable composite index. Ratings agencies have indicated that the probability of securing an upgrade of sovereign credit ratings in the coming months is lower because of the floods. However, the exchange rate has remained stable.

\section{The AUthorities' Response ANd The NeEd FOR AsSistanCe}

19. The authorities' initial response has focused on emergency and relief efforts and donor mobilization. The UN has launched an appeal for funding of emergency response efforts to provide food, shelter, water and sanitation, and health services. It has appealed for US\$460 million to finance Pakistan's Initial Floods Emergency Response Plan. As of August 25, about 60 percent has been committed. Moreover, humanitarian assistance pledges (some outside the UN appeal) amount to US\$725 million as of September 1, with Saudi Arabia, the United Kingdom, and the United States, among the largest donors. Private individuals and organizations have pledged US\$93 million for humanitarian assistance so far. In the absence of a damage assessment, pledges for reconstruction financing are still at an early stage. The World Bank and the ADB have pledged to reprogram loans of US\$1 and US $\$ 2$ billion, respectively, in previously committed lending to finance reconstruction and relief efforts in flood-hit areas.

\section{The authorities' plan to work with World Bank staff on establishing an enhanced} framework for monitoring of donor contributions. Such a framework is needed to ensure that aid reaches the people harmed by the floods, especially the poor and vulnerable groups. The framework will seek to increase transparency of these flows and accountability for their use and so encourage larger and swifter aid disbursements that will help alleviate hardships suffered by these groups.

21. The fiscal framework will need to be revised to accommodate the cost of emergency operations and reconstruction. Prior to the floods, a consolidated budget deficit target of 4 percent of GDP was seen as consistent with the need to manage pressures in domestic financial markets in order to regain disinflation momentum and avoid crowding out of the private sector. The floods have created substantial need for expenditure on rescue and relief 
operations and rehabilitation and reconstruction that will increase the deficit. ${ }^{6}$ Accordingly, the budget deficit target will need to take account of these needs. However, to avoid inflationary pressure and crowding out of the private sector, the additional outlays should be financed mainly by external assistance. Hence, additional external financing is urgently needed, preferably in the form of budgetary grants or on highly concessional terms, to finance flood-related spending.

22. The government plans budget measures. To boost budgetary resources, the government has decided to introduce a temporary 10 percent income tax surcharge, which could generate up to 0.4 percent of GDP. Furthermore, the government will shift resources from nonpriority current and development spending to relief and reconstruction spending. As an initial assistance, the authorities are planning to provide Rs. 20,000 (US\$230) to people receiving benefits under the Benazir Income Support Program that have been affected by the floods (about 1 million people). Provinces have agreed to scale back their spending plans which should limit the consolidated deficit. Nonetheless, the pre-flood deficit is currently projected to be 4.4 percent of GDP, so additional measures will be needed to bring it to 4 percent of GDP and create fiscal space for flood-related spending and because room for additional domestic financing is limited.

\section{No monetary policy announcements have been made since the floods hit, but the} SBP is facing a difficult balancing act. An estimated Rs. 2 trillion in t-bills needs to be rolled over this year and there may be higher domestic net financing needs of the government on account of the floods. On the other hand, domestic private demand will soften and so undermine the already weak recovery in private sector credit growth. These considerations will have to be weighted carefully in deciding on the monetary policy stance in the coming months. The next monetary policy statement in expected in late September.

24. The SBP has focused on ensuring smooth functioning of the payment system. It has set up mobile banking facilities and made sure that ample currency was available in areas hit by the floods. It is closely monitoring banks with large exposures in the flood-hit areas. It has announced measures to encourage banks to supply sufficient credit in flood-hit areas, especially as the wheat financing season gets underway in October. It is also considering using existing SBP refinancing schemes to encourage credit in flood-hit areas. The SBP is discussing with donors expansion and modification of a loan-guarantee program to support agriculture and small and medium enterprises. The SBP is considering relaxations in provisioning for loans that have become delinquent because of the floods by allowing a higher for-sale-value of some collateral assets, which are currently zero for real assets.

\footnotetext{
${ }^{6}$ The flood-related additional spending for humanitarian needs and rehabilitation and reconstruction cannot be projected yet; an estimate should be available after the completion of damage and needs assessment by midOctober.
} 
The authorities remain committed not to impose or intensify exchange or trade restrictions for balance of payments purposes.

\section{ACCESS AND CAPACITY TO RePay}

25. The authorities have requested a purchase for an amount equivalent to SDR 296.98 million (28.73 percent of quota) under the Fund's policy of ENDA. The purchase - which represents approximately $1 / 4$ percent of Pakistan's 2010/11 GDP-will be directed to the budget. It will help finance the additional spending and the associated immediate foreign exchange needs stemming from the floods, thereby mitigating a decline in external reserves and supporting confidence in Pakistan's external position.

26. The proposed purchase would impact the Fund's exposure to Pakistan and improved fiscal performance is needed to buttress Pakistan's ability to repay the Fund, which although adequate is subject to downside risks. The most prominent downside risk is a combined shock to growth, primary budget balance, higher interest rates, and a large depreciation. GRA credit outstanding (including this purchase and access under the existing SBA) is expected to peak at 69 percent of gross international reserves, equivalent to 6 percent of GDP. Debt service payments will peak at about 25 percent of gross reserves and 14 percent of exports of goods and services in 2013/14. The authorities past record at servicing obligations to the Fund has been good.

\section{STAFF APPRAISAL}

\section{The impact of the floods has caused immense human suffering and physical}

damage. The floods have not yet receded so their full impact cannot be assessed yet. Nonetheless, they have already affected 10 percent of the population and urgent action by the government and the international community has been required to avert additional loss of life, injuries, and damage to infrastructure. Rehabilitation and reconstruction will take time and are deserving of generous support from the international community.

\section{Humanitarian relief and reconstruction expenditures are needed to respond to the} devastation caused by the floods. Given the scale of the tragedy and the limited amount of non-inflationary financing available, it would be important for this assistance to be provided as grants or on highly concessional terms. We welcome the authorities' intention to introduce a reformed GST to broaden the tax base and enhance tax revenue and to continue with the SBA, which targets macroeconomic and social stability. This will require careful management of the budget, as well as efforts to mobilize external donor support for humanitarian assistance and reconstruction, in order to avoid excessive recourse to domestic financial markets. 
29. The authorities recognize the importance of closely monitoring the disbursement and use of aid flows to ensure accountability and transparency. We welcome the authorities' plan to work with the World Bank on establishing an enhanced framework for this monitoring. Accountability and transparency will increase the amounts of aid and its speed of disbursement, so bringing quicker relief to the population, especially the poor who have been hurt most by this natural catastrophe.

30. We welcome the authorities' intention to move ahead with measures for the completion of the fifth review under the SBA. In the coming weeks, we will work with the authorities to re-evaluate the macroeconomic framework once the damage needs assessment has been completed. The floods will impact the economy significantly in 2010/11 and necessitate revisions to the budget, which will be submitted for approval to the cabinet and parliament. This will take some time but the authorities hope that the fifth review under the SBA can be completed later this year.

31. We support the authorities' request for a purchase under the Fund's policy on emergency assistance for natural disasters. The purchase will facilitate needed imports and avoid depleting Pakistan's international reserves, pending completion of the fifth review under the SBA. The steps taken by the authorities and proposed so far and the international support that has been promised are encouraging signs. 
Figure 1. Pakistan: Selected Economic Indicators
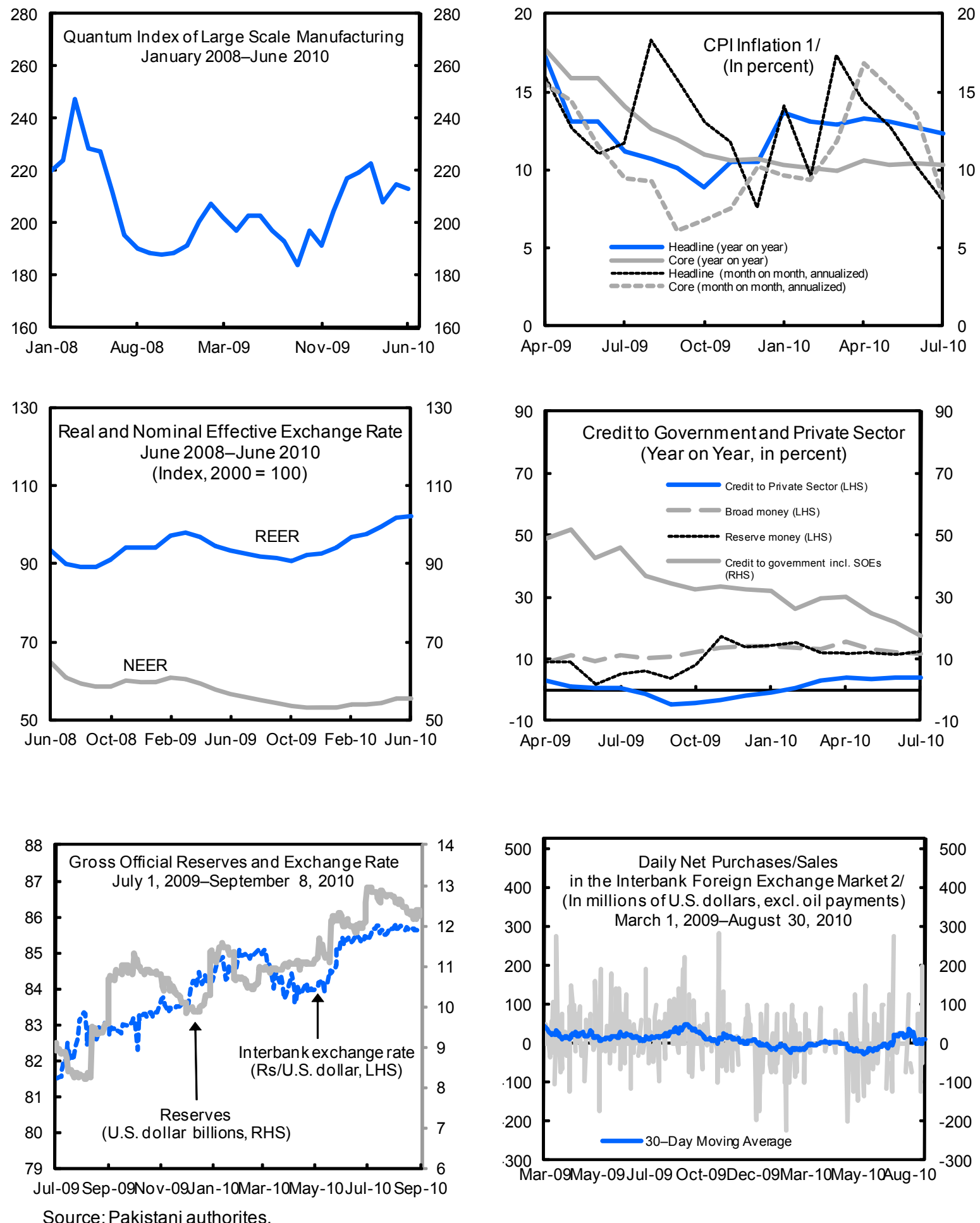

\footnotetext{
1/Annualized month on month core and headline inflation are based on a three month moving averages of the respective indices.

$2 /$ Positive values indicate net purchases in the interbank market.
} 
Figure 2. Pakistan: Financial Market Indicators
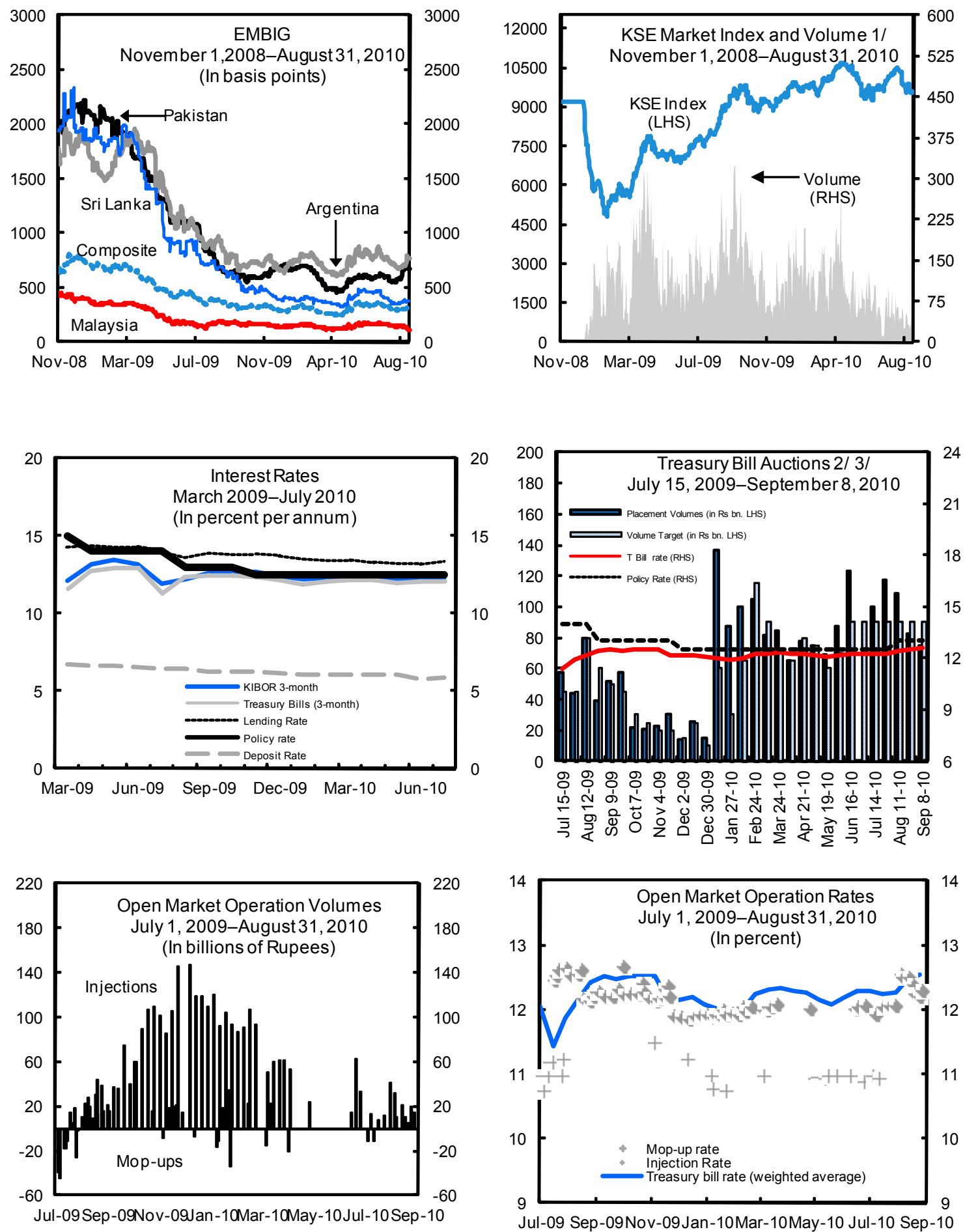

Sources: Pakistani authorities and Bloomberg.

$1 /$ Daily traded volumes are in millions of shares.

2/Placement volumes are for all maturities and the Treasury Bill rate is a weighted average.

$3 /$ On July 30 , policy rate was increased by 50 bp effective August 2 . 
Figure 3. Pakistan: Real and External Sectors, 2006/07-2010/11
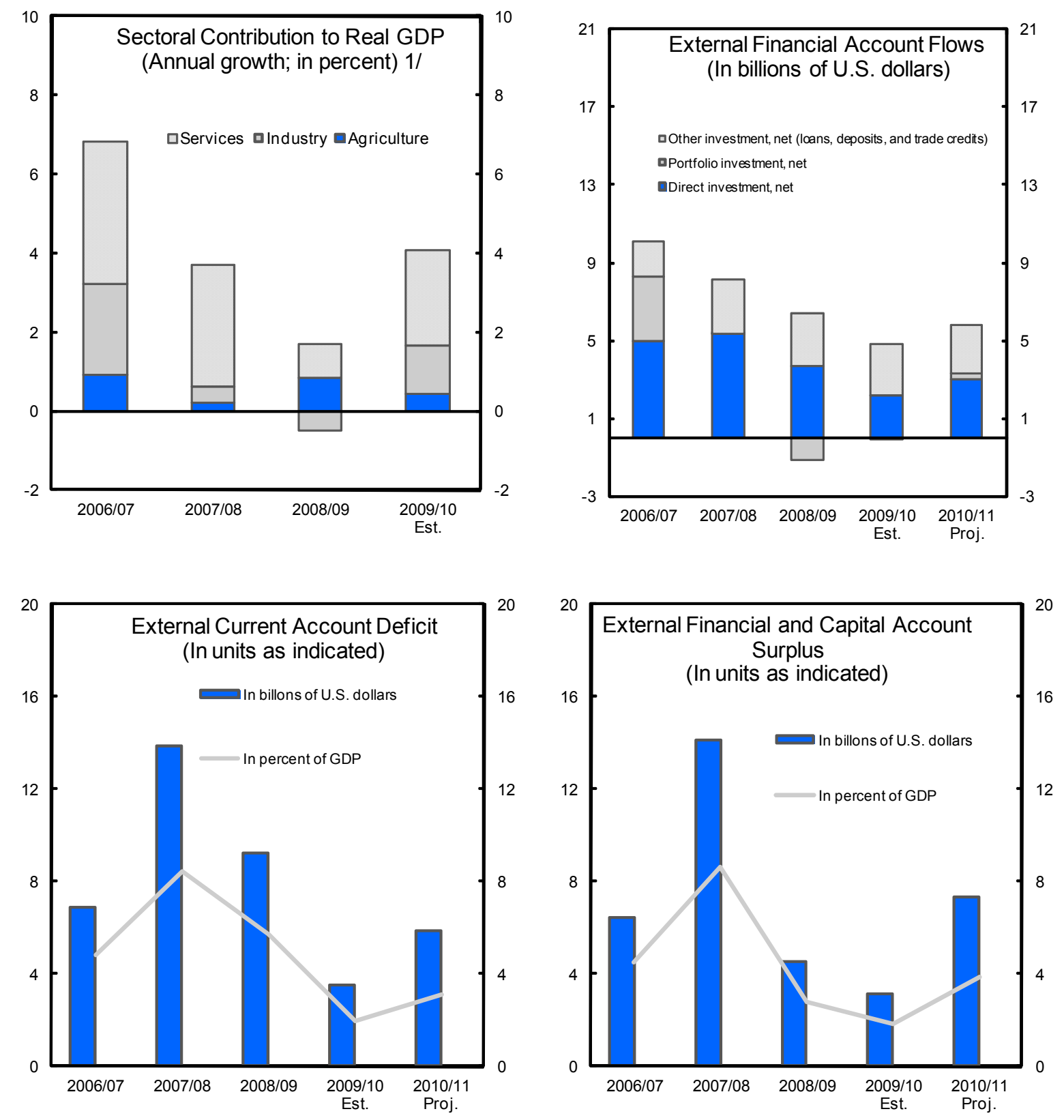

Sources: Pakistani authorities and Fund staff projections.

1/ At factor cost. 
Figure 4. Pakistan: Fiscal Policy Indicators
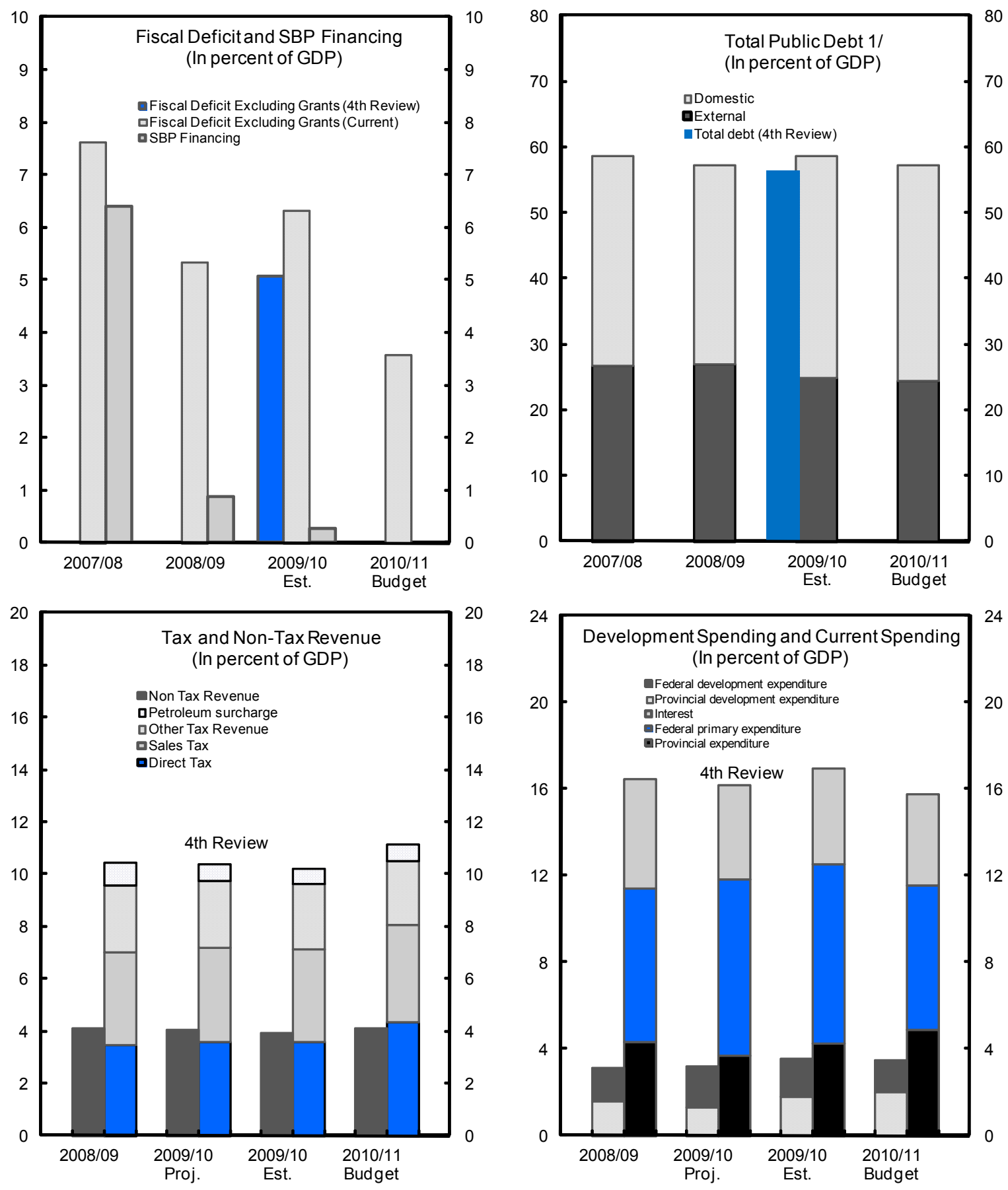

Sources: Pakistani authorities and Fund staff estimates and projections.

1/ Excluding IMF lending. 
Table 1. Pakistan: Selected Economic Indicators, 2008/09-2010/11 1/

(Population: 160.9 million (2007/08))

(Per capita GDP: US\$1,042 (2007/08))

(Poverty rate: 17.2 percent $(2007 / 08))$

\begin{tabular}{|c|c|c|c|c|}
\hline & \multirow[t]{2}{*}{$2008 / 09$} & \multirow[t]{2}{*}{$\begin{array}{r}\text { Provisional } \\
2009 / 10\end{array}$} & \multicolumn{2}{|c|}{$\begin{array}{c}\text { Projection } \\
2010 / 11\end{array}$} \\
\hline & & & Pre-flood & Post-flood \\
\hline & \multicolumn{4}{|c|}{ (Annual percentage change) } \\
\hline \multicolumn{5}{|l|}{ Output and prices } \\
\hline Real GDP at factor cost & 1.2 & 4.1 & 4.3 & 2.8 \\
\hline Partner country demand (WEO definition) & & & & \\
\hline Consumer prices (period average) & 20.8 & 11.7 & 11.5 & 13.5 \\
\hline Consumer prices (end of period) & 13.1 & 12.7 & 10.5 & 12.5 \\
\hline \multirow[t]{2}{*}{ Pakistani rupees per U.S. dollar (period average) } & 25.8 & 6.7 & $\ldots$ & $\ldots$ \\
\hline & \multicolumn{4}{|c|}{ (In percent of GDP) } \\
\hline \multicolumn{5}{|l|}{ Saving and investment } \\
\hline Gross saving & 13.2 & 14.6 & 15.2 & 16.6 \\
\hline Government & -2.1 & -2.4 & -0.3 & 0.3 \\
\hline Nongovernment (including public sector enterprises) & 15.3 & 17.0 & 15.5 & 16.3 \\
\hline Gross capital formation 2/ & 19.0 & 16.6 & 18.0 & 19.7 \\
\hline Government & 3.1 & 3.5 & 3.2 & 3.4 \\
\hline Nongovernment (including public sector enterprises) & 15.8 & 13.0 & 14.7 & 16.2 \\
\hline \multicolumn{5}{|l|}{ Public finances $3 /$} \\
\hline Revenue and grants & 14.7 & 14.5 & 15.7 & $\ldots$ \\
\hline Expenditure (including statistical discrepancy) & 19.9 & 20.5 & 19.2 & $\ldots$ \\
\hline Budget balance (including grants) & -5.2 & -6.0 & -3.6 & $\ldots$ \\
\hline Budget balance (excluding grants) & -5.3 & -6.3 & -4.0 & $\ldots$ \\
\hline Primary balance & -0.2 & -1.6 & 1.1 & $\ldots$ \\
\hline Total government debt $4 /$ & 57.3 & 58.7 & $\ldots$ & $\cdots$ \\
\hline External government debt & 27.0 & 24.9 & $\cdots$ & $\cdots$ \\
\hline Domestic government debt & 30.2 & 33.8 & $\cdots$ & $\cdots$ \\
\hline \multirow[t]{2}{*}{ Total public debt (including all obligations to the IMF) } & 60.6 & 63.4 & $\ldots$ & $\ldots$ \\
\hline & \multicolumn{4}{|c|}{$\begin{array}{l}\text { (Annual changes in percent of initial stock of broad } \\
\text { money, unless otherwise indicated) }\end{array}$} \\
\hline Monetary sector & & & & \\
\hline Net foreign assets & -3.2 & 3.0 & 2.8 & 0.8 \\
\hline Net domestic assets & 12.8 & 11.9 & $\ldots$ & 10.2 \\
\hline Broad money & 9.6 & 12.5 & $\ldots$ & 11.0 \\
\hline Private credit (percentage change) & 0.7 & 3.9 & $\cdots$ & 14.2 \\
\hline Six-month treasury bill rate (period average, in percent) & 13.1 & 12.2 & $\ldots$ & $\ldots$ \\
\hline \multicolumn{5}{|l|}{ External sector } \\
\hline Merchandise exports, U.S. dollars (percentage change) & -6.4 & 2.7 & 4.7 & 3.0 \\
\hline Merchandise imports, U.S. dollars (percentage change) & -10.3 & -2.2 & 6.9 & 8.7 \\
\hline Current account balance (in percent of GDP) & -5.7 & -2.0 & -2.4 & -3.1 \\
\hline & \multicolumn{4}{|c|}{$\begin{array}{c}\text { (In percent of exports of goods and services, } \\
\text { unless otherwise indicated) }\end{array}$} \\
\hline External public and publicly guaranteed debt & 182.2 & 172.4 & $\ldots$ & 169.4 \\
\hline Debt service & 21.6 & 19.7 & $\ldots$ & 14.6 \\
\hline Gross reserves (in millions of U.S. dollars) $5 /$ & 9,110 & 12,958 & 17,888 & 16,746 \\
\hline In months of next year's imports of goods and services & 2.9 & 3.7 & 4.6 & 4.6 \\
\hline \multicolumn{5}{|l|}{ Memorandum items: } \\
\hline Real effective exchange rate (annual average, percentage change) & -1.6 & $\ldots$ & $\ldots$ & $\ldots$ \\
\hline Terms of trade (percentage change) & 11.1 & $\ldots$ & $\ldots$ & $\ldots$ \\
\hline Real per capita GDP (percentage change) & -0.5 & 2.3 & 2.5 & 1.1 \\
\hline GDP at market prices (in billions of Pakistani rupees) & 12,739 & 14,668 & 17,124 & 17,107 \\
\hline GDP at market prices (in billions of U.S. dollars) & 162.0 & 174.8 & 190.7 & 190.2 \\
\hline
\end{tabular}

Sources: Pakistani authorities; and Fund staff estimates and projections.

1/ Fiscal year ends June 30

2/ Including changes in inventories. Investment data recorded by the Pakistan Federal Bureau of Statistics are said to underreport true activity.

3/ The "pre-flood" column shows data for 2010/11 budget.

4/ Excludes obligations to the IMF except budget financing, military debt, commercial loans, and short-term debt.

5/ Excluding gold and foreign currency deposits of commercial banks held with the State Bank of Pakistan.

\section{CInternational Monetary Fund. Not for Redistribution}


Table 2. Pakistan: Balance of Payments, 2008/09-2010/11

(In millions of U.S. dollars; unless otherwise indicated)

\begin{tabular}{|c|c|c|c|c|}
\hline & \multirow[b]{3}{*}{$2008 / 09$} & \multirow[b]{2}{*}{ Est. } & \multicolumn{2}{|c|}{ Proj. 1/ } \\
\hline & & & Pre-Flood & Post-Flood \\
\hline & & $2009 / 10$ & \multicolumn{2}{|c|}{$2010 / 11$} \\
\hline Current account & $-9,261$ & $-3,495$ & $-4,624$ & $-5,861$ \\
\hline Balance on goods & $-12,627$ & $-11,423$ & $-12,604$ & $-13,524$ \\
\hline Exports, f.o.b. & 19,121 & 19,632 & 20,551 & 20,230 \\
\hline Imports, f.o.b. & $-31,747$ & $-31,055$ & $-33,155$ & $-33,754$ \\
\hline Services (net) & $-3,381$ & $-1,677$ & $-1,357$ & $-1,965$ \\
\hline Services: credit & 4,106 & 5,148 & 5,983 & 5,940 \\
\hline Services: debit & $-7,487$ & $-6,825$ & $-7,339$ & $-7,905$ \\
\hline Income (net) & $-4,407$ & $-3,269$ & $-3,708$ & $-3,776$ \\
\hline Income: credit & 874 & 562 & 620 & 620 \\
\hline Income: debit & $-5,281$ & $-3,831$ & $-4,328$ & $-4,396$ \\
\hline Of which: interest payments & $-2,030$ & $-1,451$ & $-1,773$ & $-1,836$ \\
\hline Of which: income on direct investment & $-3,192$ & $-2,358$ & $-2,530$ & $-2,530$ \\
\hline Balance on goods, services, and income & $-20,415$ & $-16,369$ & $-17,669$ & $-19,265$ \\
\hline Current transfers (net) & 11,154 & 12,874 & 13,045 & 13,403 \\
\hline Current transfers: credit, of which: & 11,256 & 12,984 & 13,220 & 13,578 \\
\hline Official & 210 & 591 & 123 & 306 \\
\hline Workers' remittances & 7,811 & 8,906 & 9,467 & 9,822 \\
\hline Other private transfers & 3,235 & 3,487 & 3,630 & 3,450 \\
\hline Current transfers: debit & -102 & -110 & -175 & -175 \\
\hline Capital account & 455 & 184 & 763 & 549 \\
\hline Capital transfers: credit & 460 & 189 & 766 & 552 \\
\hline Of which: official capital grants & 427 & 163 & 766 & 552 \\
\hline Capital transfers: debit & -5 & -5 & -3 & -3 \\
\hline Financial account & 5,377 & 4,770 & 5,962 & 5,821 \\
\hline Direct investment abroad & -25 & 8 & -50 & -50 \\
\hline Direct investment in Pakistan & 3,720 & 2,201 & 3,280 & 3,080 \\
\hline Of which: privatization receipts & 0 & 0 & 800 & 800 \\
\hline Portfolio investment (net), of which: & $-1,073$ & -64 & 428 & 278 \\
\hline Equity Securities & -552 & 588 & 450 & 300 \\
\hline Debt Securities & -521 & -652 & -22 & -22 \\
\hline Financial derivatives (net) & 0 & 0 & 0 & 0 \\
\hline Other investment assets & 305 & 267 & -220 & -170 \\
\hline Monetary authorities & -255 & 262 & 0 & 0 \\
\hline General government & 8 & -1 & 0 & 0 \\
\hline Banks & 346 & 380 & -120 & -120 \\
\hline Other sectors & 206 & -374 & -100 & -50 \\
\hline Other investment liabilities & 2,450 & 2,358 & 2,524 & 2,683 \\
\hline Monetary authorities & -1 & 1,150 & 0 & -100 \\
\hline General government, of which: & 1,948 & 1,048 & 1,341 & 1,633 \\
\hline Disbursements & 4,190 & 3,627 & 3,052 & 3,344 \\
\hline Amortization & $-2,268$ & $-2,579$ & $-1,711$ & $-1,711$ \\
\hline Banks & 291 & -17 & -17 & -50 \\
\hline Other sectors & 212 & 177 & 1,200 & 1,200 \\
\hline Net errors and omissions & 118 & -425 & 0 & 0 \\
\hline Reserves and related items & 3,311 & $-1,034$ & $-2,101$ & -509 \\
\hline Reserve assets, of which: & -380 & $-4,325$ & $-5,310$ & $-4,168$ \\
\hline Foreign exchange (State Bank of Pakistan) & -446 & $-4,212$ & $-4,930$ & $-3,788$ \\
\hline Foreign exchange (deposit money banks) & 66 & -113 & -380 & -380 \\
\hline Use of Fund credit and loans & 3,691 & 3,292 & 3,209 & 3,659 \\
\hline Of which: purchases & 3,902 & 3,531 & 3,470 & 3,920 \\
\hline Exceptional financing & 0 & 0 & 0 & 0 \\
\hline \multicolumn{5}{|l|}{ Memorandum items: } \\
\hline Current account (in percent of GDP) & -5.7 & -2.0 & -2.4 & -3.1 \\
\hline Current account (in percent of GDP; excluding fuel imports) & 0.2 & 3.8 & 3.3 & 2.7 \\
\hline Exports f.o.b. (growth rate, in percent) & -6.4 & 2.7 & 4.7 & 3.0 \\
\hline Imports f.o.b. (growth rate, in percent) & -10.3 & -2.2 & 6.9 & 8.7 \\
\hline Crude oil price (\$/bbl) & 68.5 & 73.6 & 73.8 & 74.8 \\
\hline Workers' remittances and other private transfers & & & & \\
\hline (growth rate, in percent) & -0.8 & 12.2 & 4.5 & 7.1 \\
\hline External debt (in millions of U.S. dollars) & 52,000 & 55,265 & 58,558 & 60,401 \\
\hline Gross financing needs (in millions of U.S. dollars) $2 /$ & 12,196 & 6,935 & 7,253 & 7,855 \\
\hline End-period gross official reserves (millions of U.S. dollars) $3 /$ & 9,110 & 12,958 & 17,888 & 16,746 \\
\hline (In months of next year's imports of goods and services) & 2.9 & 3.7 & 4.6 & 4.6 \\
\hline (in percent of debt service) & 183.5 & 297.6 & 414.3 & 387.8 \\
\hline GDP (in millions of U.S. dollars) & 161,994 & 174,792 & 190,665 & 190,204 \\
\hline
\end{tabular}

Sources: Pakistani authorities; and Fund staff estimates and projections.

1/ Post-flood projections include revisions unrelated to the floods including oil prices and projections for non-flood related capital transfers.

2/ Defined as current account deficit, plus amortization on medium- and long-term debt, plus short-term debt at end of previous period. 3/ Excluding foreign currency deposits held with the State Bank of Pakistan (cash reserve requirements) and gold.

\section{CInternational Monetary Fund. Not for Redistribution}


Table 3a. Pakistan: Consolidated Government Budget, 2008/09-2010/11 (In billions of Pakistani rupees)

\begin{tabular}{|c|c|c|c|}
\hline & & Est. & $\begin{array}{c}\text { Authorities' } \\
\text { Budget 1/ }\end{array}$ \\
\hline & $2008 / 09$ & $2009 / 10$ & $2010 / 11$ \\
\hline Revenue and grants & 1,872 & 2,130 & 2,684 \\
\hline Revenue & 1,851 & 2,079 & 2,607 \\
\hline Tax revenue & 1,331 & 1,500 & 1,907 \\
\hline Federal & 1,285 & 1,445 & 1,831 \\
\hline FBR revenue & 1,157 & 1,329 & 1,689 \\
\hline Direct taxes & 440 & 529 & 736 \\
\hline Federal excise duty & 116 & 121 & 141 \\
\hline Sales tax/VAT & 452 & 517 & 639 \\
\hline Customs duties & 148 & 161 & 173 \\
\hline Petroleum surcharge & 112 & 89 & 110 \\
\hline Gas surcharge and other & 16 & 28 & 32 \\
\hline Provincial & 46 & 55 & 76 \\
\hline Nontax revenue & 520 & 579 & 700 \\
\hline Federal & 436 & 512 & 634 \\
\hline Provincial & 84 & 68 & 66 \\
\hline Grants & 22 & 51 & 77 \\
\hline Of which: IDP grants & $\ldots$ & 36 & $\ldots$ \\
\hline Expenditure & 2,497 & 3,040 & 3,292 \\
\hline Current expenditure & 2,093 & 2,482 & 2,696 \\
\hline Federal & 1,547 & 1,855 & 1,866 \\
\hline Interest & 638 & 642 & 717 \\
\hline Domestic & 559 & 578 & 640 \\
\hline Foreign & 79 & 64 & 77 \\
\hline Other & 909 & 1,213 & 1,149 \\
\hline Of which: subsidies & 244 & 227 & 132 \\
\hline Of which: grants & 136 & 361 & 267 \\
\hline Of which: Cash transfers to poor households $2 /$ & 21 & 55 & 45 \\
\hline Provincial & 546 & 627 & 830 \\
\hline Development expenditure and net lending & 404 & 558 & 597 \\
\hline Public Sector Development Program & 398 & 519 & 590 \\
\hline Federal & 196 & 260 & 250 \\
\hline Of which: One-off expenditure & 27 & 25 & 0 \\
\hline Provincial & 202 & 258 & 340 \\
\hline Net lending & 7 & 39 & 7 \\
\hline Statistical discrepancy ("+" = additional expenditure) 3/ & 34 & -35 & 0 \\
\hline Overall Deficit (excluding grants) & -680 & -926 & -685 \\
\hline Overall Deficit (including grants) & -659 & -876 & -608 \\
\hline Financing & 659 & 876 & 608 \\
\hline External & 116 & 138 & 136 \\
\hline Of which: privatization receipts & 1 & 0 & 0 \\
\hline Of which: IMF & $\ldots$ & 92 & $\ldots$ \\
\hline Domestic & 543 & 737 & 472 \\
\hline Bank & 315 & 301 & 105 \\
\hline Nonbank & 227 & 436 & 350 \\
\hline \multicolumn{4}{|l|}{ Memorandum items: } \\
\hline Expenditure 4/ & 2,558 & 3,031 & 3,292 \\
\hline Primary balance (excluding grants) & -43 & -284 & 31 \\
\hline Primary balance (including grants) & -21 & -233 & 108 \\
\hline Augmented fiscal balance (excluding grants) $5 /$ & $\ldots$ & $-1,203$ & \\
\hline Defense spending & 424 & 568 & 552 \\
\hline Total government debt $6 /$ & 7,298 & 8,607 & $\ldots$ \\
\hline Domestic debt & 3,853 & 4,954 & $\ldots$ \\
\hline External debt $6 /$ & 3,446 & 3,653 & $\ldots$ \\
\hline Nominal GDP (market prices) & 12,739 & 14,668 & 17,107 \\
\hline
\end{tabular}

Sources: Pakistani authorities for historical data; and Fund staff for estimates and projections.

$1 /$ Authorities' budget projections, augmented with revenue measures adopted since the floods, but not including any flood-related expenditures or tax collection losses.

2/ Comprises BISP, Bait-ul-Mal, and Pakistan Poverty Alleviation Fund.

3/ The statistical discrepancy is believed to arise mainly from double-counting of spending at the provincial level.

4/ Includes statistical discrepancy and spending related to the 2005 earthquake.

5/ Reflects assumption of electricity sector debt by the budget.

6/ Excludes obligations to the IMF except budget financing, military debt, commercial loans, and short-term debt.

\section{CInternational Monetary Fund. Not for Redistribution}


Table 3b. Pakistan: Consolidated Government Budget, 2008/09-2010/11 (In percent of GDP; unless otherwise indicated)

\begin{tabular}{|c|c|c|c|}
\hline & & Est. & $\begin{array}{c}\text { Authorities' } \\
\text { Budget 1/ }\end{array}$ \\
\hline & $2008 / 09$ & $2009 / 10$ & $2010 / 11$ \\
\hline Revenue and grants & 14.7 & 14.5 & 15.7 \\
\hline Revenue & 14.5 & 14.2 & 15.2 \\
\hline Tax revenue & 10.4 & 10.2 & 11.2 \\
\hline Federal & 10.1 & 9.9 & 10.7 \\
\hline FBR revenue & 9.1 & 9.1 & 9.9 \\
\hline Direct taxes & 3.5 & 3.6 & 4.3 \\
\hline Federal excise duty & 0.9 & 0.8 & 0.8 \\
\hline Sales tax/VAT & 3.6 & 3.5 & 3.7 \\
\hline Customs duties & 1.2 & 1.1 & 1.0 \\
\hline Petroleum surcharge / Carbon tax & 0.9 & 0.6 & 0.6 \\
\hline Gas surcharge and other & 0.1 & 0.2 & 0.2 \\
\hline Provincial & 0.4 & 0.4 & 0.4 \\
\hline Nontax revenue & 4.1 & 4.0 & 4.1 \\
\hline Federal & 3.4 & 3.5 & 3.7 \\
\hline Provincial & 0.7 & 0.5 & 0.4 \\
\hline Grants & 0.2 & 0.3 & 0.5 \\
\hline Of which: IDP grants & $\ldots$ & 0.2 & $\ldots$ \\
\hline Expenditure & 19.6 & 20.7 & 19.2 \\
\hline Current expenditure & 16.4 & 16.9 & 15.8 \\
\hline Federal & 12.1 & 12.6 & 10.9 \\
\hline Interest & 5.0 & 4.4 & 4.2 \\
\hline Domestic & 4.4 & 3.9 & 3.7 \\
\hline Foreign & 0.6 & 0.4 & 0.4 \\
\hline Other & 7.1 & 8.3 & 6.7 \\
\hline Of which: subsidies & 1.9 & 1.5 & 0.8 \\
\hline Of which: grants & 1.1 & 2.5 & 1.6 \\
\hline Of which: Cash transfers to poor households $2 /$ & 0.2 & 0.4 & 0.3 \\
\hline Provincial & 4.3 & 4.3 & 4.9 \\
\hline Development expenditure and net lending & 3.2 & 3.8 & 3.5 \\
\hline Public Sector Development Program & 3.1 & 3.5 & 3.4 \\
\hline Federal & 1.5 & 1.8 & 1.5 \\
\hline Of which: One-off expenditure & 0.2 & 0.2 & 0.0 \\
\hline Provincial & 1.6 & 1.8 & 2.0 \\
\hline Net lending & 0.1 & 0.3 & 0.0 \\
\hline Statistical discrepancy (“+" = additional expenditure) 3/ & 0.3 & -0.2 & 0.0 \\
\hline Overall Deficit (excluding grants) & -5.3 & -6.3 & -4.0 \\
\hline Overall Deficit (including grants) & -5.2 & -6.0 & -3.6 \\
\hline Financing & 5.2 & 6.0 & 3.6 \\
\hline External & 0.9 & 0.9 & 0.8 \\
\hline Of which: privatization receipts & 0.0 & 0.0 & 0.0 \\
\hline Of which: IMF & $\ldots$ & 0.6 & $\ldots$ \\
\hline Domestic & 4.3 & 5.0 & 2.8 \\
\hline Bank & 2.5 & 2.1 & 0.6 \\
\hline Nonbank & 1.8 & 3.0 & 2.0 \\
\hline \multicolumn{4}{|l|}{ Memorandum items: } \\
\hline Expenditure 4/ & 20.1 & 20.7 & 19.2 \\
\hline Primary balance (excluding grants) & -0.3 & -1.9 & 0.2 \\
\hline Primary balance (including grants) & -0.2 & -1.6 & 0.6 \\
\hline Augmented fiscal balance (excluding grants) $5 /$ & $\ldots$ & -8.2 & $\ldots$ \\
\hline Total security spending & 3.3 & 3.9 & 3.2 \\
\hline Total government debt 6 / & 57.3 & 58.7 & $\ldots$ \\
\hline Domestic debt & 30.2 & 33.8 & $\ldots$ \\
\hline External debt 6/ & 27.0 & 24.9 & $\ldots$ \\
\hline Nominal GDP (market prices, billions of Pakistani rupees) & 12,739 & 14,668 & 17,107 \\
\hline
\end{tabular}

Sources: Pakistani authorities for historical data; and Fund staff for estimates and projections.

1/ Authorities' budget projections, augmented with revenue measures adopted since the floods, but not including any flood-related expenditures or tax collection losses.

2/ Comprises BISP, Bait-ul-Mal, and Pakistan Poverty Alleviation Fund.

$3 /$ The statistical discrepancy is believed to arise mainly from double-counting of spending at the provincial level. 4/ Includes statistical discrepancy and spending related to the 2005 earthquake.

5/ Reflects assumption of electricity sector debt by the budget.

6/ Excludes obligations to the IMF except budget financing, military debt, commercial loans, and short-term debt.

\section{CInternational Monetary Fund. Not for Redistribution}


Table 4. Pakistan: Monetary Survey and Analytical Balance Sheet of the State Bank of Pakistan, 2007/08-2010/11

\begin{tabular}{|c|c|c|c|c|c|}
\hline & \multirow[b]{3}{*}{$2007 / 08$} & \multirow[b]{3}{*}{$2008 / 09$} & \multicolumn{2}{|c|}{ Act. } & \multirow{2}{*}{$\begin{array}{c}\text { Proj } \\
\text { Jun. 4/ }\end{array}$} \\
\hline & & & Jun. $3 /$ & Jun. $4 /$ & \\
\hline & & & \multicolumn{2}{|c|}{$2009 / 10$} & $2010 / 11$ \\
\hline & \multicolumn{5}{|c|}{ (In billions of Pakistani rupees) } \\
\hline \multicolumn{6}{|l|}{ Monetary survey } \\
\hline Net foreign assets (NFA) & 668 & 517 & 670 & 545 & 593 \\
\hline Budget support, of which: & 1,325 & 1,630 & 1,935 & 1,935 & 2,040 \\
\hline Banks & 310 & 500 & 763 & 763 & 910 \\
\hline Commodity operations & 127 & 336 & 413 & 413 & 413 \\
\hline Credit to nongovernment & 3,018 & 3,190 & 3,389 & 3,389 & 3,917 \\
\hline Private sector & 2,904 & 2,924 & 3,037 & 3,037 & 3,467 \\
\hline Public sector enterprises & 114 & 266 & 352 & 352 & 450 \\
\hline Privatization account & -3 & -3 & -3 & -3 & -3 \\
\hline Foreign currency deposits & 263 & 280 & 345 & 345 & 389 \\
\hline \multicolumn{6}{|l|}{ State Bank of Pakistan (SBP) } \\
\hline NFA & 480 & 324 & 504 & 379 & 374 \\
\hline NDA & 1,000 & 1,183 & 1,175 & 1,300 & 1,512 \\
\hline Net claims on government & 1,015 & 1,144 & 1,187 & 1,187 & 1,145 \\
\hline Of which: budget support & 1,016 & 1,130 & 1,171 & 1,171 & 1,130 \\
\hline Claims on nongovernment & -7 & -7 & -6 & -6 & -7 \\
\hline Claims on scheduled banks & 227 & 303 & 313 & 313 & 425 \\
\hline Privatization account & -3 & -3 & -3 & -3 & -3 \\
\hline Other items, net & -231 & -254 & -316 & -191 & -49 \\
\hline Reserve money, of which: & 1,480 & 1,508 & 1,679 & 1,679 & 1,886 \\
\hline Banks' reserves & 425 & 274 & 290 & 290 & 297 \\
\hline Budgetary support (in percent of broad money) 1/ & 12.5 & 6.5 & 5.9 & $\ldots$ & 1.8 \\
\hline NFA, banking system & -32.2 & -22.5 & 29.6 & $\ldots$ & 8.7 \\
\hline NDA, banking system & 30.6 & 14.9 & 10.5 & $\ldots$ & 11.2 \\
\hline Budgetary support & 62.4 & 23.0 & 18.7 & $\ldots$ & 5.4 \\
\hline Private credit & 16.4 & 0.7 & 3.9 & $\ldots$ & 14.2 \\
\hline Currency & 16.9 & 17.3 & 12.4 & $\ldots$ & 15.5 \\
\hline Reserve money & 22.3 & 1.9 & 11.4 & $\ldots$ & 12.3 \\
\hline NFA, SBP (in percent of reserve money) $1 /$ & -25.4 & -10.5 & 11.9 & $\ldots$ & -0.3 \\
\hline NDA, SBP (in percent of reserve money) $1 /$ & 47.7 & 12.4 & -0.5 & $\cdots$ & 12.6 \\
\hline Net claims on government (in percent of reserve money) $1 /$ & 56.9 & 8.6 & 2.6 & $\ldots$ & -2.5 \\
\hline \multicolumn{6}{|l|}{ Memorandum items: } \\
\hline Velocity & 2.2 & 2.5 & 2.5 & $\ldots$ & 2.7 \\
\hline Money multiplier & 3.2 & 3.4 & 3.4 & $\ldots$ & 3.4 \\
\hline Currency to broad money ratio (percent) & 20.9 & 22.4 & 22.4 & $\ldots$ & 23.3 \\
\hline Currency to deposit ratio (percent) & 26.5 & 28.9 & 28.9 & $\ldots$ & 30.4 \\
\hline Foreign currency to deposit ratio (percent) & 7.1 & 7.0 & 7.7 & $\ldots$ & 7.9 \\
\hline Reserves to deposit ratio (percent) & 11.5 & 6.9 & 6.5 & $\ldots$ & 6.0 \\
\hline Budget bank financing (billions of Pakistani rupees), of which: & 509 & 305 & 305 & $\ldots$ & 105.0 \\
\hline By commercial banks & -167 & 191 & 263 & $\ldots$ & 147 \\
\hline By SBP & 677 & 114 & 42 & $\ldots$ & -42 \\
\hline NFA of SBP (change from beginning of the year in billions of U.S. dollars) $2 /$ & -4.5 & -3.1 & 1.9 & $\ldots$ & -0.5 \\
\hline NFA of commercial banks (millions of U.S. dollars) & 2,748 & 2,370 & 1,948 & $\ldots$ & 2,328 \\
\hline NDA of commercial banks (billions of Pakistani rupees) & 3,022 & 3,437 & 3,931 & $\ldots$ & 4,308 \\
\hline Excess reserves in percent of broad money & 1.5 & 0.3 & -0.2 & $\ldots$ & $\ldots$ \\
\hline
\end{tabular}

Sources: Pakistani authorities for historical data; and Fund staff estimates and projections.

1 / Denominator is the stock of broad (reserve) money at the end of the previous year.

2/ Includes valuation adjustments.

3 / SDR allociation treated as Equity.

4 / SDR allociation treated as SBP Foreign Liability. 
Table 5. Pakistan: Medium-Term Macroeconomic Framework, 2007/08-2014/15

\begin{tabular}{|c|c|c|c|c|c|c|c|c|}
\hline & \multirow[b]{2}{*}{$2007 / 08$} & \multirow[b]{2}{*}{$2008 / 09$} & \multirow{2}{*}{$\frac{\text { Provisional }}{2009 / 10}$} & \multicolumn{5}{|c|}{ Projections } \\
\hline & & & & $2010 / 11$ & $2011 / 12$ & $2012 / 13$ & $2013 / 14$ & $2014 / 15$ \\
\hline & \multicolumn{8}{|c|}{ (Annual changes in percent) } \\
\hline \multicolumn{9}{|l|}{ Output and prices } \\
\hline Real GDP at factor cost & 3.7 & 1.2 & 4.1 & 2.8 & 4.0 & 5.0 & 5.5 & 6.0 \\
\hline Consumer prices (period average) & 12.0 & 20.8 & 11.7 & 13.5 & 9.5 & 7.0 & 6.0 & 6.0 \\
\hline & \multicolumn{8}{|c|}{ (In percent of GDP) } \\
\hline Saving and investment balance & -8.5 & -5.7 & -2.0 & -3.1 & -3.6 & -3.9 & -4.1 & -4.2 \\
\hline Government & -7.3 & -5.2 & -6.0 & -3.1 & -2.5 & -2.4 & -1.8 & -1.6 \\
\hline Non-government (including public sector enterprises) & -1.2 & -0.5 & 4.0 & 0.0 & -1.2 & -1.5 & -2.4 & -2.7 \\
\hline Gross national saving $1 /$ & 13.6 & 13.2 & 14.6 & 16.6 & 17.6 & 18.7 & 19.7 & 20.9 \\
\hline Government & -2.9 & -2.1 & -2.4 & 0.3 & 1.0 & 1.5 & 2.0 & 2.3 \\
\hline Non-government (including public sector enterprises) & 16.5 & 15.3 & 17.0 & 16.3 & 16.7 & 17.2 & 17.7 & 18.6 \\
\hline Gross capital formation & 22.1 & 19.0 & 16.6 & 19.7 & 21.3 & 22.6 & 23.8 & 25.1 \\
\hline Government & 4.4 & 3.1 & 3.5 & 3.4 & 3.4 & 3.9 & 3.8 & 3.9 \\
\hline Non-government (including public sector enterprises) & 17.6 & 15.8 & 13.0 & 16.2 & 17.8 & 18.8 & 20.0 & 21.2 \\
\hline & \multicolumn{8}{|c|}{ (In billions of U.S. dollars, unless otherwise indicated) } \\
\hline \multicolumn{9}{|l|}{ Balance of payments } \\
\hline Current account balance & -13.9 & -9.3 & -3.5 & -5.9 & -7.3 & -8.3 & -9.4 & -10.3 \\
\hline Net capital flows 2/ & 1.3 & 0.8 & 1.0 & 1.0 & 1.1 & 1.1 & 1.1 & 1.2 \\
\hline Of which: foreign direct investment $3 /$ & 5.4 & 3.7 & 2.2 & 3.1 & 4.0 & 4.5 & 5.2 & 5.7 \\
\hline Gross official reserves & 8.6 & 9.1 & 13.0 & 16.7 & 18.2 & 18.7 & 17.9 & 16.5 \\
\hline In months of imports 4/ & 2.6 & 2.9 & 3.7 & 4.6 & 4.8 & 4.6 & 4.2 & 3.6 \\
\hline \multirow[t]{2}{*}{ External debt (in percent of GDP) } & 27.1 & 32.1 & 31.6 & 31.8 & 32.6 & 32.5 & 31.3 & 29.1 \\
\hline & \multicolumn{8}{|c|}{ (In percent of GDP) } \\
\hline \multicolumn{9}{|l|}{ Public finances 1/ } \\
\hline Revenue and grants & 14.9 & 14.7 & 14.5 & 15.7 & 15.9 & 16.3 & 16.6 & 16.6 \\
\hline Of which: tax revenue & 10.6 & 10.4 & 10.2 & 11.2 & 11.6 & 12.2 & 12.5 & 12.9 \\
\hline Expenditure (incl. stat. discr.), of which: & 22.2 & 19.9 & 20.5 & 19.2 & 18.4 & 18.7 & 18.3 & 18.2 \\
\hline Current & 18.1 & 16.4 & 16.9 & 15.8 & 14.9 & 14.8 & 14.5 & 14.3 \\
\hline Development (incl. net lending) & 4.1 & 3.2 & 3.8 & 3.5 & 3.4 & 3.9 & 3.8 & 3.9 \\
\hline Primary balance $5 /$ & -2.4 & 0.1 & -1.3 & 0.6 & 1.9 & 1.8 & 2.2 & 1.8 \\
\hline Overall fiscal balance 5 / & -7.3 & -5.2 & -6.0 & -3.6 & -2.5 & -2.4 & -1.8 & -1.6 \\
\hline Total public debt (including obligations to the IMF) & 59.6 & 60.6 & 63.4 & 63.7 & 61.3 & 58.6 & 54.7 & 49.2 \\
\hline \multicolumn{9}{|l|}{ Memorandum item } \\
\hline Real per capita consumption (percentage change) & 5.0 & 6.5 & 1.4 & 0.8 & 1.5 & 2.0 & 2.2 & 2.5 \\
\hline
\end{tabular}

Sources: Pakistani authorities for historical data; and Fund staff estimates and projections.

1/ For 2010/11 authorities' budget projections, augmented with revenue measures adopted since the floods, but not including any flood-related expenditures or tax collection losses.

2/ Difference between the overall balance and the current account balance.

3/ Including privatization.

4/ In months of next year's imports of goods and services.

$5 /$ Including grants. 
Table 6. Pakistan: Indicators of Fund Credit, 2008/09-2015/16 1/

(In millions of SDR unless otherwise specified)

\begin{tabular}{|c|c|c|c|c|c|c|c|c|}
\hline & \multirow[b]{2}{*}{ 2008/09 } & \multirow[b]{2}{*}{$2009 / 10$} & \multicolumn{6}{|c|}{ Projections } \\
\hline & & & $2010 / 11$ & $2011 / 12$ & $2012 / 13$ & $2013 / 14$ & $2014 / 15$ & $2015 / 16$ \\
\hline & \multicolumn{8}{|c|}{ (Projected Debt Service to the Fund based on Existing and Prospective Drawings) } \\
\hline \multicolumn{9}{|l|}{ ECF } \\
\hline Principal 2/ & 137.7 & 155.0 & 172.3 & 163.6 & 120.6 & 51.7 & 17.2 & 0.0 \\
\hline Interest and charges 2 / & 4.0 & 1.7 & 0.0 & 0.3 & 0.3 & 0.1 & 0.0 & 0.0 \\
\hline \multicolumn{9}{|l|}{ Stand-By Arrangements and Proposed purchase under ENDA } \\
\hline Principal & 0.0 & 0.0 & 0.0 & 587.9 & $1,726.1$ & $2,493.8$ & $1,969.3$ & 755.8 \\
\hline \multirow[t]{2}{*}{ Interest and charges } & 42.9 & 55.6 & 133.9 & 179.1 & 166.7 & 89.4 & 28.0 & 6.6 \\
\hline & \multicolumn{8}{|c|}{ (Projected Level of Credit Outstanding based on Existing and Prospective Drawings) } \\
\hline Total & $3,316.4$ & $5,461.5$ & $7,886.1$ & $7,134.5$ & $5,287.8$ & $2,742.3$ & 755.8 & 0.0 \\
\hline ECF Arrangements & 680.5 & 525.5 & 353.2 & 189.6 & 69.0 & 17.3 & 0.0 & 0.0 \\
\hline \multirow[t]{2}{*}{ Stand-By Arrangements and Proposed purchase under ENDA } & $2,635.9$ & $4,936.0$ & $7,532.9$ & $6,945.0$ & $5,218.9$ & $2,725.1$ & 755.8 & 0.0 \\
\hline & \multicolumn{8}{|c|}{ (Projected Debt Service to the Fund based on Existing and Prospective Drawings) } \\
\hline Total $2 /$ & 184.6 & 212.4 & 306.2 & 931.0 & $2,013.6$ & $2,635.0$ & $2,014.5$ & 762.4 \\
\hline \multicolumn{9}{|l|}{ Of which: } \\
\hline Principal & 137.7 & 155.0 & 172.3 & 751.6 & $1,846.7$ & $2,545.5$ & $1,986.5$ & 755.8 \\
\hline Interest and charges & 46.9 & 57.4 & 133.9 & 179.4 & 167.0 & 89.5 & 28.0 & 6.6 \\
\hline In percent of exports of goods and non-factor services & 1.2 & 1.3 & 1.8 & 5.3 & 10.9 & 13.5 & 9.8 & 3.5 \\
\hline In percent of GDP & 0.2 & 0.2 & 0.2 & 0.7 & 1.5 & 1.8 & 1.3 & 0.4 \\
\hline In percent of end-period gross international reserves & 3.0 & 2.4 & 2.8 & 7.7 & 16.3 & 22.2 & 18.5 & 6.7 \\
\hline \multicolumn{9}{|l|}{ Memorandum items } \\
\hline Exports of goods and NFS (in millions of U.S. dollars) & 23,227 & 24,780 & 26,170 & 26,758 & 28,199 & 29,803 & 31,323 & 32,825 \\
\hline Quota & 1,034 & & & & & & & \\
\hline GDP (in millions of U.S. dollars) & 161,994 & 174,792 & 190,204 & 198,958 & 211,912 & 226,990 & 244,385 & 263,112 \\
\hline Fund credit outstanding (in percent of GDP) & 3.2 & 4.6 & 6.3 & 5.4 & 3.8 & 1.8 & 0.5 & 0.0 \\
\hline Of which: SBA and proposed purchase under ENDA & 2.5 & 4.2 & 6.0 & 5.3 & 3.7 & 1.8 & 0.5 & 0.0 \\
\hline Gross international reserves (in millions of U.S. dollars) & 9,110 & 12,958 & 16,746 & 18,249 & 18,701 & 17,950 & 16,534 & 17,167 \\
\hline
\end{tabular}

Source: Fund staff projections.

1/ Including proposed purchase under the ENDA.

2/ For 2008/09, debt service includes payments related to EFF. 


\section{APPENDIX I. PAKISTAN: RELATIONS WITH THE FUND}

As of July 31, 2010

I. Membership Status: Joined: 07/11/1950; Article VIII

II. General Resources Account:

Quota

Fund Holdings of Currency

Reserve position in Fund

III. SDR Department:

Net cumulative allocation

Holdings

IV. Outstanding Purchases and Loans:

Stand-by Arrangements

ECF arrangements $\underline{\text { SDR Million }}$

$1,033.70$

$5,969.62$

0.12

SDR Million
988.56
854.07

$\underline{\text { SDR Million }}$

$4,936.04$

499.62
\% Quota

100.00

577.50

0.01

$\%$ Allocation

100.00

86.40

\% Quota

477.51

48.33

V. Latest Financial Arrangements:

\begin{tabular}{|c|c|c|c|c|}
\hline Type & $\begin{array}{l}\text { Approval } \\
\text { Date }\end{array}$ & $\begin{array}{c}\text { Expiration } \\
\text { Date }\end{array}$ & $\begin{array}{c}\text { Amount Approved } \\
\text { (SDR Million) }\end{array}$ & $\begin{array}{l}\text { Amount Drawn } \\
\text { (SDR Million) }\end{array}$ \\
\hline Stand-By & $11 / 24 / 2008$ & $12 / 30 / 2010$ & $7,235.90$ & $4,936.04$ \\
\hline $\mathrm{ECF}$ & $12 / 06 / 2001$ & $12 / 05 / 2004$ & $1,033.70$ & 861.42 \\
\hline Stand-By & $11 / 29 / 2000$ & $09 / 30 / 2001$ & 465.00 & 465.00 \\
\hline
\end{tabular}

\section{Projected Payments to the Fund ${ }^{1,2}$}

(SDR Million; based on existing use of resources and present holdings of SDRs):

\begin{tabular}{lrrrrr} 
& \multicolumn{5}{c}{ Forthcoming } \\
\cline { 2 - 6 } & $\mathbf{2 0 1 0}$ & $\mathbf{2 0 1 1}$ & $\mathbf{2 0 1 2}$ & $\mathbf{2 0 1 3}$ & $\mathbf{2 0 1 4}$ \\
Principal & 60.30 & 172.28 & $1,418.11$ & $2,362.48$ & $1,230.80$ \\
Charges/Interest & 49.73 & 102.29 & 92.80 & 45.57 & 13.11 \\
Total & 110.03 & 274.58 & $1,510.91$ & $2,408.05$ & $1,243.92$
\end{tabular}

\footnotetext{
${ }^{1}$ This schedule presents all currently scheduled payments to the IMF, including repayment expectations and repayment obligations. The IMF Executive Board can extend repayment expectations (within predetermined limits) upon request by the member if its external payment position is not strong enough to meet the expectations without undue hardship or risk.

${ }^{2}$ When a member has overdue financial obligations outstanding for more than three months, the amount of such arrears will be shown in this section.
} 


\section{Exchange System}

On May 19, 1999, the dual exchange system was unified, with all international transactions conducted at the interbank market exchange rate (FIBR). The Fund classifies Pakistan's exchange rate regime as floating. Pakistan has accepted the obligations of Article VIII, sections 2, 3, and 4. Pakistan is maintaining an exchange system free of restrictions on the making of payments and transfers for current international transactions following the elimination of the cash margin requirements on letters of credit in June 2009 and of restrictions on advance import payments against letters of credit in January 2010.

\section{Last Article IV Consultation}

The last Article IV consultation (Country Report 09/123) was discussed by the Executive Board on March 23, 2009.

\section{Safeguards Assessments}

An update of the March 2009 safeguards assessment was completed in February 2010 in relation to the augmentation of access under the Stand-By Arrangement. The assessment found that: (i) efforts are continuing to strengthen the safeguards framework at the SBP, including improved transparency and a more proactive role by the Audit Committee; (ii) the SBP's legal framework continues to present a safeguards risk due to an unclear timetable for enacting amendments to the SBP Act, which address the autonomy of SBP and management of foreign reserves; and (iii) the treatment and use of Fund resources for budgetary support has been clarified in an agreement between the SBP and the Ministry of Finance. In their official response, the authorities agreed to the proposed timetable for implementation of most measures.

\section{FSAP Participation and ROSCs}

\begin{tabular}{|l|c|l|}
\hline Fiscal Transparency Module & $11 / 28 / 2000$ & (www.imf.org) \\
\hline Fiscal Transparency Module-Update & $11 / 22 / 2004$ & Country Report No. 04/416 \\
\hline $\begin{array}{l}\text { Financial System Stability Assessment } \\
\text { Financial Sector Assessment Program }\end{array}$ & $6 / 23 / 2004$ & Country Report No. 04/215 \\
\hline $\begin{array}{l}\text { Data Module and Detailed Assessment Using } \\
\text { Quality Assessment Framework }\end{array}$ & $11 / 29 / 2004$ & Country Report No. 04/398 \\
\hline $\begin{array}{l}\text { Data Module, Reassessment of Monetary } \\
\text { Statistics and Detailed Assessment Using } \\
\text { Quality Assessment Framework }\end{array}$ & $2 / 2 / 2007$ & Country Report No. 07/74 \\
\hline Fiscal Transparency Module-Draft Update & $2 / 13 / 2007$ & Country Report No. 08/129 \\
\hline $\begin{array}{l}\text { Financial System Stability Assessment, } \\
\text { Financial Sector Assessment Program Update }\end{array}$ & $9 / 22 / 2008$ & In progress \\
\hline
\end{tabular}




\section{Recent Technical Assistance}

\section{FAD}

January 2002: Fiscal data management, quality, and transparency. January 2003: Tax administration.

February/March 2003: Customs administration.

April 2004: Fiscal reporting.

April 2007: Public financial management.

July and November 2009: Valued Added Tax law.

\section{MCM}

November/December 2004: Public debt reform and capacity building program (joint with World Bank).

March/April 2005: Development of the Insurance Sector.

December 2006: Monetary policy framework.

April 2007: Monetary policy framework, the SBP's balance sheet, and the Banking Services Corporation.

\section{STA}

February 2002: External sector statistics/SDDS subscription.

April/May 2005: National accounts and consumer price statistics.

May 2007: Statistics on the international investment position.

October 2009: Multisector statistics (remote technical assistance).

\section{LEG}

July 2008: Deposit Protection Fund.

July 2008: Central Bank Law.

August 2008: Banking Law.

\section{Resident Representative}

A resident representative has been stationed in Islamabad since August 1991. The current resident representative Mr. Paul Ross took up his post in October 2008. 
Islamabad, Pakistan

September 10, 2010

Mr. Dominique Strauss-Kahn

Managing Director

International Monetary Fund

Washington, DC 20431

Dear Mr. Strauss-Kahn:

The floods that hit Pakistan in late July and August are a natural disaster of massive proportions. Some 1,540 people have died, a further 2,320 have been injured, and more than 2 million families have been displaced. Over 15 million people (almost 10 percent of the population) have been affected and large parts of the country, from the Chinese border to the mouth of the Indus River, have been flooded. Although fewer casualties have been sustained than after the 2005 earthquake, the damage to economic infrastructure and private property is much more severe.

It is too soon for a precise estimate of the economic fallout and reconstruction cost, but undoubtedly we will need substantial support. The World Bank and the Asian Development Bank (ADB) will provide a Damages and Needs Assessment by mid-October. But, it is already clear that our needs will far exceed our means.

We are, therefore, seeking rapid assistance from the IMF to help us cope with the immediate economic impact of this disaster, and request a purchase under the policy on Emergency Assistance for Natural Disasters (ENDA) in the amount of SDR 296.98201 million (28.73 percent of quota). The assistance will be used to meet the immediate financing needs of the government for providing urgent food, shelter, and health services without overburdening domestic financial markets or depleting foreign exchange reserves. Financial assistance from the IMF will also help sustain confidence in our external position during these difficult times, and encourage financing from other sources. We remain very much committed to the reforms we are undertaking under the Stand-By Arrangement (SBA), as discussed in our letter of May 3, 2010 to the Fund, and hope to be able to complete the fifth review under the program in the coming months.

\section{Economic and Budgetary Developments before the Floods}

Even before the floods, our economic circumstances were far from easy, but we were making progress with our stabilization and reform program. Manufacturing activity had rebounded in recent months and real GDP growth in 2009/10 reached 4.1 percent according to provisional estimates. We had been on track to reach at least $4 \frac{1}{2}$ percent GDP growth this year. Inflation 
had come down from 25 percent in October 2008 to $12-13$ percent in recent months. To contain inflation, in July the State Bank increased its policy interest rate by 50 basis points to 13 percent. Gross reserves reached US\$13 billion in June 2010, and the exchange rate has been stable around $85-86$ rupees per dollar. The pickup in reserves resulted from a steady narrowing of the current account deficit, to US\$3.5 billion (2 percent of GDP) in 2009/10.

Fiscal policy faced a number of challenges in 2009/10. The reorganization of the tax administration had a temporary adverse impact on tax collection and, despite our efforts, tax collection fell short of target. At the same time, there were overruns in security spending due to the difficult security situation, and provincial spending was higher than expected. Consequently, the 2009/10 fiscal deficit reached 6.3 percent of GDP, compared with an unadjusted program target of 5.1 percent and an adjusted target of 4.6 percent of GDP. Although we were able to draw on domestic bank and non-bank financing, we also had to rely on central bank financing, which exceeded the target by Rs. 42 billion. We have met all other end-June performance criteria under the Fund-supported program.

Our budget for fiscal year 2010/11, set before the floods, targets a deficit of 4 percent of GDP - a federal fiscal deficit of 5 percent of GDP combined with a provincial surplus of 1 percent of GDP. To achieve this target, we have raised the general sales tax (GST) rate by 1 percent and increased some excise and direct taxes. We have also resumed tax audits, using risk-based selection criteria to increase their efficacy.

We have also worked closely with the provinces to ensure they run the desired surpluses. The share of tax revenues distributed to them increased significantly under the 7 th National Finance Commission award. As spending responsibilities have not yet been transferred to the provinces as envisaged following the $18^{\text {th }}$ constitutional amendment, the provinces were expected to save the additional funds and run surpluses. They have agreed to revise initial budgets and scale back spending plans.

\section{Economic and Budgetary Impact of the Floods}

The floods have destroyed infrastructure and seriously undermined the economic outlook. Agriculture, which accounts for 21 percent of GDP and 45 percent of employment, has been hit particularly hard. There is significant damage to cotton, rice, and sugarcane crops as well as livestock. This will hurt our export performance, especially in the textile sector, and will lower domestic demand in other sectors. We expect GDP growth to be $2 \frac{1}{2}-3$ percent this year, about $13 / 4$ percentage points lower than would have been possible without the floods. Furthermore, the damage to crops and the disruption of supply chains in rural areas will inevitably lead to higher inflation for food and other items. Additional demand for building material, medicine, and social services will also contribute to price pressures. We expect the average annual inflation rate to increase from 11.7 percent to $13 \frac{1}{2} 2$ percent this year. The financial sector is also suffering, with dozens of bank branches closed in flood-hit areas.

While it is presently difficult to estimate with any accuracy, the floods will have considerable budgetary impact. The rescue and relief operations and the costs of repairing and rebuilding 
public infrastructure will place a heavy burden on public finances at both the provincial and the federal level. At the same time, tax revenues are likely to fall as economic activity weakens. The floods will likely hurt the balance of payments. Imports will rise in the short run as food and other basic goods will need to be sourced from abroad, while capital equipment imports will increase when reconstruction begins.

\section{Our Response to the Floods}

The Government of Pakistan has moved swiftly to provide relief and mobilize resources. The National Disaster Management Authority, its provincial counterparts, and other agencies have made great efforts to provide rescue and relief operations in the areas affected by the floods. Thousands of people have been evacuated, food and medicine have been distributed to displaced persons, and some emergency repairs have been made to roads and other infrastructure.

Donors have responded with emergency assistance, aid pledges, and reallocation of resources. The United Nations has led the effort for early recovery and assistance operations for which it needs US\$460 million, of which so far it has secured US\$275 million from public and private international donors. Also, the World Bank and the ADB have committed to reallocate US\$1 and US\$2 billion, respectively, to help us finance reconstruction.

The cost of emergency operations and the reconstruction that lies ahead will compel us to adapt our fiscal framework to boost budgetary resources and enable the government to address the emergency, improve service delivery to the population, and increase public investment to raise growth. We will, therefore, shift resources from non-priority current and development spending to relief and reconstruction spending. We will also introduce a temporary 10 percent income tax surcharge. Despite these efforts, there is no doubt that the massive spending needs and the revenue shortfall that are being caused by the floods will push the deficit above 4 percent of GDP. Given the limitations on domestic resources, additional external financing is urgently needed, preferably in the form of budgetary grants.

The SBP is taking steps to limit the damage to the economy and the financial sector. It is working closely with banks to facilitate the flow of credit and also with international development agencies to expand and redirect the existing financing facilities to small and medium-size enterprises and microfinance projects in the areas hit by the floods. And, to make sure Pakistan's international trade and financial relations continue to function normally, we will not impose any restrictions on the making of payments and transfers for current international transactions nor introduce any trade restrictions or enter into any bilateral payment agreements that are inconsistent with Article VIII of the Fund's Articles of Agreement.

We will continue to co-operate closely with the Fund in the context of our SBA, both to provide support for our reform efforts and help provide a consistent economic and financial framework in the challenging period ahead. Specifically, the existing GST will be transformed through the introduction of a reformed GST capturing the features of a VAT, enabling us to start raising the tax revenues required for sustainable growth. We also remain committed to reform the electricity sector in order to eliminate tariff differential subsidies 
and resolve circular debt, and to address the quasi-fiscal implications of commodity credit. We will adopt measures to cap the fiscal deficit at 4 percent of GDP before the impact of the flood. The macroeconomic framework will be re-evaluated once the damage needs assessment has been completed, and a revised budget will be submitted for approval to the cabinet and presented to the standing committees on finance and revenue of the National Assembly and the Senate of Pakistan. We are working actively to deliver these reforms and thus remain confident that the fifth review under the SBA can be completed later this year.

Sincerely,

$/ \mathrm{s} /$

Abdul Hafeez Shaikh

Minister of Finance
$/ \mathrm{s} /$

Shahid H. Kardar

Governor of the State Bank of Pakistan 
September 15, 2010

\section{IMF Executive Board Approves US\$451 Million Disbursement in Emergency Natural Disaster Assistance for Pakistan}

The Executive Board of the International Monetary Fund (IMF) today approved a disbursement of an amount equivalent to SDR 296.98 million (about US\$451 million) under the Emergency Natural Disaster Assistance (ENDA) for Pakistan to help the country manage the immediate aftermath of the massive and devastating floods that have hit the country. The Board's approval enables the immediate disbursement of the full amount of this emergency assistance; with the hope that this disbursement will catalyze and speed an adequate level of disbursements by other members of the international community.

Pakistan's economic outlook has deteriorated sharply as a result of the floods. The agriculture sector, which accounts for 21 percent of Gross Domestic Product (GDP) and 45 percent of employment, has been hit particularly hard. Initial and preliminary assessments suggest that real GDP growth is unlikely to exceed $23 / 4$ percent in $2010 / 11$, mainly because of sharply lower agricultural output. Owing to the disruptions in economic activity, pressure on the country's budget is expected as well as a weakening of the balance of payments position. An updated estimate on the economic impact of the floods should be available after the completion of damage and needs assessment in the fall.

The US\$451 million in emergency assistance will be directed to the country's budget. It will help finance the additional spending to help the population affected by the floods and the associated immediate foreign exchange needs, thereby mitigating a decline in external reserves and supporting confidence in Pakistan's external position.

The ENDA, which provides rapid and flexible financial assistance for countries affected by natural disasters with an urgent balance of payments need, is not linked to any programbased conditionality or review. Pakistan's financing under the ENDA carries the IMF's basic rate of charge, has a three-year and three month grace period, and is repaid in eight equal installments with a final maturity of 5 years. 
Following the Executive Board's discussion on the Pakistan, Mr. Naoyuki Shinohara, Deputy Managing Director and Acting Chair, stated:

"The IMF extends its deep sympathy to the people of Pakistan for the loss of life, human suffering, and extensive damage to property and infrastructure caused by catastrophic floods since late July. The adverse impact of the floods has resulted in significant fiscal and balance of payments needs related to relief operations.

"The authorities' immediate response to provide relief to victims and mobilize humanitarian aid is commendable. The Fund's emergency assistance to Pakistan will help finance needed imports and is expected to catalyze additional external support - preferably in the form of grants or highly concessional financing — which is critical to help meet the immediate budgetary and balance of payments needs and avoid excessive recourse to domestic financing. The authorities will work with the World Bank on an enhanced monitoring of aid flows to help target assistance to the poor and vulnerable and bolster transparency and accountability.

"The authorities' commitment to move ahead with the introduction of a reformed general sales tax, aimed at broadening the tax base, and a strategy for reforming the electricity sector will be important in addressing the budgetary situation and help facilitate the completion of the fifth review under the Stand-By Arrangement." 


\section{Statement by Jafar Mojarrad, Executive Director for Pakistan}

My Pakistani authorities wish to convey their deepest appreciation to the Fund Executive Board and management for their continued support and invaluable advice. They also thank Fund staff for their constructive engagement with the authorities and their hard work. My authorities broadly agree with the staff's assessment, in particular with the challenges facing the country at this very difficult time, and look forward to continued close cooperation with the Fund.

\section{Performance Prior to the Floods}

The key economic indicators for 2009/10 confirm that before the floods, the Pakistani economy was picking up. Estimates showed that real GDP, led by manufacturing, grew at 4.1 percent; annual average inflation fell to 11.7 percent (with core inflation at 10.4 percent); the current account deficit narrowed sharply to 2 percent of GDP; official reserves increased to about US\$13 billion; and the nominal exchange rate remained broadly stable. This performance, which owed much to the authorities' perseverance with reform, despite a complex and costly security situation and a difficult external environment, brought rating agencies to consider upgrading the sovereign credit rating just before the country was hit by the most devastating catastrophe in recent history.

While program targets on growth, and the external position were met, and average inflation was only marginally above the target, the fiscal situation did not improve as expected, mainly reflecting increased spending on security and the fight against terrorism, higher provincial spending, and a temporary shortfall in tax revenue following the reorganization of the tax administration and court appeals by taxpayers. Nontax revenue also fell below target due to lower dividends and profit transfers. As a result, the fiscal deficit (excluding grants) reached 6.3 percent of GDP, compared to an unadjusted target of 5.1 percent of GDP, and the endJune target on government borrowing from the State Bank of Pakistan (SBP) was missed by 0.3 percent of GDP. My authorities are committed to bringing the SBA-supported program back on track, including through strengthened fiscal consolidation efforts.

The 2010/11 approved federal budget targets a general government deficit of 4 percent of GDP. Towards its realization, my authorities immediately implemented a number of measures. On July 1, the general sales tax (GST) rate was raised by 1 percentage point to 17 percent. In addition, some excise and direct taxes were increased and capital gains tax exemptions withdrawn. Sustained efforts are being made to improve tax administration, including through strengthened audits. Moreover, following extensive consultations with the provinces, active discussions with the Fund and World Bank staffs on the modalities for the introduction of a reformed GST are underway. Savings are also contemplated on the spending side, including cuts in subsidies and a nominal freeze in federal current spending. 
Monetary policy remains focused on price stability while supporting stable growth. To this end, in late July the policy rate was raised by 50 basis points. Banking sector liquidity remained high and return on assets and equity improved.

Progress was also made on electricity reforms. The tariff was raised on July 1 by 7.6 percent - rather than 6 percent - to offset the financial impact of the three-month delay. Discussions on a comprehensive reform strategy for the electricity sector with the World Bank and the Asian Development Bank (ADB) resumed with the objective of reaching an early agreement needed to release about US\$1 billion of program loans to help finance the 2010/11 budget.

\section{The Floods and their Impact}

The catastrophic floods that have hit Pakistan have led to an immense human tragedy and severely harmed the economy. As a result, the economic outlook has weakened considerably. Growth is expected to be lower, and the fiscal, BOP, and inflation situations are expected to worsen.

More than two million families have been displaced and over twenty million people have been affected. There is extensive damage to roads, telecommunication, energy infrastructure, and private property. Precise estimates are not yet available because of the scale of the disaster, but the costs arising from the floods will amount to billions of dollars. The World Bank and ADB will submit a Damages and Needs assessment by mid-October.

Agriculture, which accounts for 21 percent of GDP and 45 percent of employment, has been particularly hard hit. An estimated 8 percent of total cropped area has been flooded, with very significant damage to food and industrial crops that will hurt export performance, especially in the textile sector. Manufacturing output and exports have also been affected. As a result, GDP growth is expected to drop to 2.5-3.0 percent in 2010/11, much lower than the 4.25 percent projected before the floods. The decline in output growth could be higher if the damage to crops exceeds preliminary assessments or if the floods recede at a slower pace than expected. Furthermore, inflation is expected to be higher due to lower agricultural output, disruptions in the supply chains, and demand pressures on building materials, medicines, and social services.

The floods are expected to weaken the BOP by close to 1 percent of GDP. The current account deficit is projected to increase, as a result of larger imports of food and other basic goods as well as capital equipment imports for reconstruction, which will only be partially offset by increased remittances. This would lead to pressure on reserves, which have already fallen by US\$700 million since end-June.

Tax revenues are likely to be lower than projected before the floods because of the floodinduced weakening of economic activity. At the same time demand for budgetary resources 
is expected to increase significantly because of the rescue and relief operations and the huge reconstruction needs. Cognizant of this need, my authorities are committed to the reform efforts aimed at increasing internal revenue generation and putting public finances on a sustainable footing.

\section{The Authorities' Response}

The Government has moved swiftly to provide relief to victims and mobilize resources for humanitarian purposes. Thousands of people have been evacuated, food and medicines have been distributed to displaced persons, and some roads and other infrastructure have seen some emergency repairs. Donors have responded with emergency assistance, aid pledges, and reallocation of resources, for which the authorities are grateful.

In addition to the needed donor support, the huge cost of emergency operations and reconstruction will require a redeployment of budgetary resources. Accordingly, my authorities plan to shift resources from nonpriority current and development spending to relief and reconstruction spending. They will also introduce a temporary 10 percent income tax surcharge. The large spending needs and revenue shortfall caused by the floods will push the deficit in 2010/11 above 4 percent of GDP. Given the limited domestic resources and in view of the urgent need for additional external financing at this crucial juncture, my authorities are requesting emergency financing under the Fund's ENDA. This financing will help meet the urgent food, shelter, and health services needs without overburdening the domestic financial markets or the reserves position. Full support of the Executive Board for my authorities' request would be much appreciated.

Despite some potential increase in NPLs, the impact of the floods on the banking system is likely to be limited. Moreover, the SBP is taking steps to limit this impact. It is working closely with banks to facilitate the flow of credit and also with the international development agencies to expand and redirect the existing financing facilities to small- and medium-sized enterprises and microfinance projects in areas hit by the floods.

\section{Conclusion}

My authorities are fully committed to the current SBA-supported program and are endeavoring to put the program back on track, as in addition to sustaining the needed resource flow, it provides the framework for economic reforms. My authorities have demonstrated commitment by remaining focused on the objectives of the SBA even in the face of the massive natural disaster. Accordingly, they plan to cap the budget deficit target to 4 percent of GDP, excluding the impact of the floods, introduce a reformed GST that captures the features of VAT on October 1, reform the electricity sector in order to eliminate subsidies and resolve circular debt, and address the quasi-fiscal implications of commodity credit.

In view of the pressing challenges brought about by the floods, support from the Fund and development partners remains crucial to shore up my authorities' emergency response to the floods. 